\title{
The human myc gene family: structure and activity of L-myc and an L-myc pseudogene
}

\author{
Ronald A. DePinho, Kimi S. Hatton, Abeba Tesfaye, George D. Yancopoulos, and Frederick W. Alt \\ The Howard Hughes Medical Institute and The Department of Biochemistry and Microbiology, College of Physicians and \\ Surgeons of Columbia University, New York, New York, 10032 USA
}

\begin{abstract}
We have determined the nucleotide sequence and transforming activity of the human L-myc gene and a processed L-myc pseudogene (L-myc $\psi$ ). We demonstrate by cotransformation assays that a 10.6-kb EcoRI fragment derived from a human placental library contains a complete and functional L-myc gene including transcriptional regulatory sequences sufficient for expression in rat embryo fibroblasts. Organization of the Lmyc gene was determined by comparing its sequence to those of the L-myc $\psi$ gene and an L-myc cDNA clone derived from a human small cell lung carcinoma. Our results show that L-myc has a three-exon organization similar to that of the c-myc and $\mathrm{N}-m y c$ genes. The putative L-myc gene product consists of 364 amino acids and contains five of the seven homology regions highly conserved between c-myc and $\mathrm{N}$-myc. These conserved regions are located along the entire length of the putative L-myc protein and are interspersed among nonconserved regions. While the putative L-myc gene product is of a smaller size when compared to the c-and $\mathrm{N}$-myc proteins, the relative positions of certain conserved residues occur in corresponding locations along the peptide backbone of the three proteins. In addition, comparison of the human and murine L-myc gene sequences indicate that the relatively large $5^{\prime}$ and $3^{\prime}$ untranslated regions are evolutionarily conserved, but that these sequences are totally divergent between the $\mathrm{L}-_{-}, \mathrm{c}_{-}$, and $\mathrm{N}$-myc genes. Finally, we demonstrate that, like the $\mathrm{N}$ - and c-myc genes, the L-myc gene can cooperate with a mutant Ha-ras gene to cause malignant transformation of rat embryo fibroblasts in culture. Our analyses clearly prove that L-myc represents a functional member of the myc oncogene family and further delineate structural features that may be important for the common and divergent functions of the members of this gene family.
\end{abstract}

[Key Words: Nucleotide sequences; cDNA; cotransformation assay; processed pseudogene; myc gene family] Received September 9, 1987; revised version accepted October 20, 1987.

The myc oncogene family consists of three known members: c-, N-, and L-myc (for review, see Alt et al. 1986; DePinho et al. 1987). The c-myc gene was first identified as the cellular homolog of an avian retroviral transforming gene, v-myc (Sheiness and Bishop 1979). Amplified $\mathrm{N}-\mathrm{myc}$ genes were identified in human neuroblastomas on the basis of homology to the c-myc gene (Kohl et al. 1983; Schwab et al. 1983). The c-myc and N-myc genes have a three-exon organization with a major coding domain located within exons 2 and 3 (Battey et al. 1982; DePinho et al. 1986; Kohl et al. 1986; Stanton et al. 1986). They encode similarly sized nuclear phosphoproteins (Abrams et al. 1982; Donner et al. 1982; Alitalo et al. 1983; Hann et al. 1983; Ikegaki et al. 1986; Persson et al. 1986; Ramsay et al. 1986; Sullivan et al. 1986; Slamon et al. 1986) which contain highly conserved clusters of amino acids (DePinho et al. 1986; Kohl et al. 1986; Stanton et al. 1986) that are likely to be important for nuclear targeting (Stone et al. 1986), nucleic acid binding (Donner et al. 1982; Persson and Leder 1984; Watt et al. 1985; Spector et al. 1987), and in vitro transforming activities (Land et al. 1983; Schwab et al.
1985; Yancopoulos et al. 1985; Stone et al. 1987). L-myc was identified first as a myc-related sequence that was amplified in a subset of human small cell lung carcinomas (SCLC) (Nau et al. 1985) and independently isolated from normal murine and human genomes on the basis of homology to N-myc (Zimmerman et al. 1986; see below). Limited nucleotide sequence analysis of a portion of the human L-myc gene revealed two short stretches of nucleotide sequence that were highly homologous to sequences conserved between the $\mathrm{N}$ - and c-myc genes (Nau et al. 1985), suggesting that L-myc might be an additional member of the myc gene family.

The physiological role of myc-family genes is not known; however, it is generally believed that these genes play a fundamental role in cellular proliferation and perhaps differentiation (for review, see Alt et al. 1986; Kelly and Siebenlist 1986). That they serve essential but distinct physiological function(s) is strongly supported by conservation of $\mathrm{c}^{-}, \mathrm{N}-$, and $\mathrm{L}-\mathrm{myc}$ as independent sequences over a large phylogenetic distance (King et al. 1986; Van Beneden et al. 1986; Collum and Alt, unpubl.). A potential role for c-myc expression in 
development was suggested by the observation that deregulated expression of this gene affects B-cell differentiation in transgenic mice (Adams et al. 1985) as well as the differentiation of myeloid erythroleukemias in vitro (Coppola and Cole 1986; Dmitrovsky et al. 1986; Lachman et al. 1986). Analysis of myc-family gene expression during murine (Jakobovits et al. 1985; Zimmerman et al. 1986) and human (DePinho and Alt, in prep.) development demonstrated that the c-myc gene is expressed at substantial levels in most developing tissues; in contrast, high-level $\mathrm{N}$ - and L-myc expression is very restricted with respect to tissue and developmental stage. A striking example of differential mycfamily gene expression occurs in the B-cell differentiation pathway. Precursor B-lymphoid cells express both $\mathrm{N}$ - and c-myc, but only c-myc is expressed in later stages of B-lymphoid cell development (Zimmerman et al. 1986). These differential myc-family gene expression patterns led to the suggestion that differential or perhaps, combinatorial expression of these genes could be related to the progression of certain cell lineages through differentiation (Zimmerman et al. 1986). Recent evidence suggests that there may be additional members of the myc-family (Alt et al. 1986).

To help elucidate the potential content and function of the myc-gene family, we have isolated and determined the structure of the complete human L-myc gene and a related human genomic sequence. In addition, we have demonstrated for the first time that the human L-myc gene has oncogenic potential; the cloned gene can cooperate with an activated Ha-ras gene to cause malignant transformation of rat embryo fibroblasts in vitro. In parallel, we have also characterized the nucleotide sequence of the murine L-myc gene (Legouy et al. 1987). Our analyses define structural elements that may be important for overlapping and distinct $m y c$ protein properties and point to sequences that could potentially serve a regulatory role in myc gene expression. Together, our findings demonstrate the L-myc represents a third functional member of the myc-family of cellular oncogenes.

\section{Results}

\section{Isolation and structural characterization of the L-myc} gene

To determine if myc-related sequences, in addition to $\mathrm{N}$ and $c-m y c$, existed in the human genome, we assayed EcoRI-digested human genomic DNA by Southern blotting procedures for hybridization with second and third exon probes derived from $\mathrm{N}-$, $\mathrm{c}-$, and $\mathrm{v}-\mathrm{myc}$ genes. Under low stringency conditions, these probes hybridized to numerous fragments that did not correspond to either the N- or c-myc genes (Alt et al. 1986). The novel mychomologous fragments that hybridized to an N-myc exon 2 probe were isolated from a human genomic library that was prepared by cloning human placental DNA digested to completion with EcoRI into the $\lambda$ vector Charon 30A. Two recombinant phage clones, R1.3 and R11.1, that hybridized strongly to probes derived from exons 2 and 3 of both the c-, and $\mathrm{N}-\mathrm{myc}$ genes were characterized in detail. Restriction mapping and hybridization experiments demonstrated that regions cross-hybridizing with exons 2 and 3 were closely positioned in the $8.8-\mathrm{kb}$ R1.3 insert and widely separated in the $10.6-\mathrm{kb}$ R11.1 insert. Preliminary sequence analyses revealed that phage clone $\mathrm{R} 11.1$ contained the short stretch of sequences previously identified within a partial human L-myc clone (Nau et al. 1985) and that phage clone R1.3 harbored stretches of sequence highly related to those of R11.1. To examine the structure and organization of these L-myc-related human sequences, we determined the nucleotide sequence of the appropriate regions of both clones; clone R11.1 (referred to hereafter as $\mathrm{L}-m y c)$ was found to contain the entire L-myc genomic sequence and the clone R1.3 (referred to hereafter as L-myc $\psi$ ) was found to contain a processed L-myc pseudogene (Figs. 1 and 2; and see below). Comparison of the L-myc genomic nucleotide sequence with the processed $\mathrm{L}-m y c \&$ sequence indicates that L-myc contains three regions of significant homology with L-myc $\psi$ separated by large stretches of unrelated sequence (Fig. 1). At each of the boundaries between conserved (exons) and divergent sequence (introns), there exists a consensus donor and acceptor splice recognition sequence (Mount 1982) (Fig. 1C).

To confirm L-myc intron/exon structure suggested by the L-myc $\psi$ gene, we prepared a $\lambda$ phage Charon 16A cDNA library from cytoplasmic poly $(\mathrm{A})^{+}$mRNA of H510 SCLC cell line and from that of an L-myc-transformed rat embryo fibroblast (REF) cell line. A 5'-L-mycexon 3 synthetic oligonucleotide primer (Fig. 1B) or oligo(dT) primer was hybridized to cytoplasmic RNA and extended as described previously (Kohl et al. 1986; Legouy et al. 1987). Recombinant phage were screened for hybridization to various L-myc probes (Fig. 2, L-myc probes $1-4 \mid$. Several cDNA clones were identified that hybridized to probes containing putative L-myc exon 1 and exon 2 sequences. Characterization of multiple cDNA clones by restriction mapping, nucleotide sequence determination, and $\mathrm{S} 1$ nuclease protection experiments indicates that several distinct L-myc transcripts result from the differential processing of the first intron (with some species retaining the first intron) and from the alternative utilization of polyadenylation signals located in the second intron (DePinho and Alt, in prep.). Direct nucleotide sequence analysis of one such primer-extended cDNA clone, pPEIII.5, confirmed the intron/exon organization suggested by analysis of the L-myc $\psi$ gene (see above). Primer extension analyses (not shown) indicate that the pPEIII. 5 cDNA clone extends to within several basepairs of a major transcription initiation site (Fig. 1A, position 138); just upstream from this major cap site is a potential TATAA element (Fig. 1A, position 88 ) and a region homologous to sequences occurring near the N-myc promoter (DePinho et al. 1986). On the basis of the data presented here, however, the existence of additional 5 ' exons cannot be excluded.

The location of the polyadenylation signal downstream to the third exon of the L-myc gene (Fig. 1, position 5452) was determined by comparing the genomic 


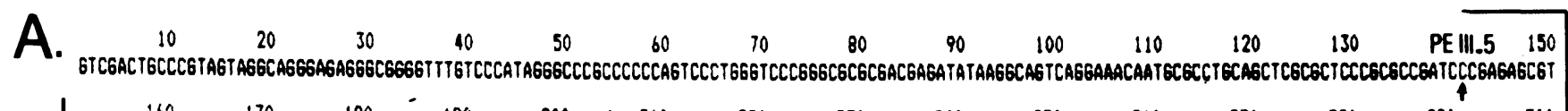

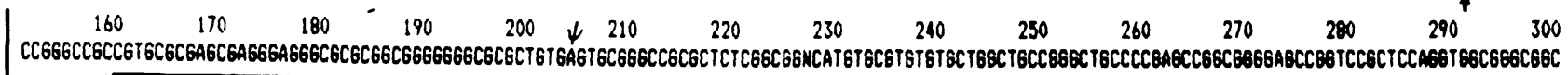

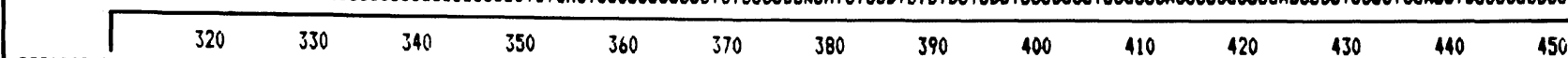

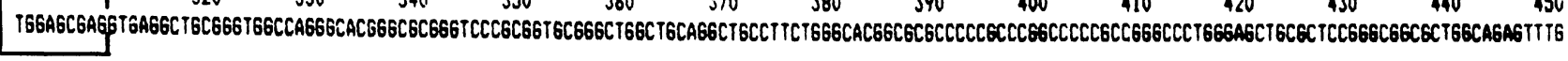

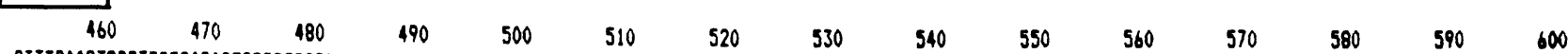

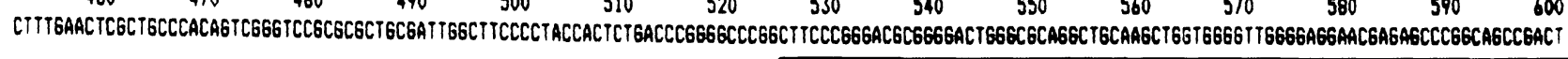

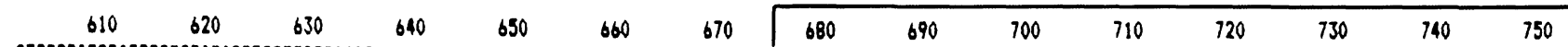

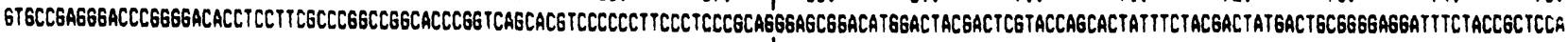
Met Asp Tyr AspSer TyrGl nHi sTyr Phe Tyr Asp Tyr AspCys6l yGl uAspPhe Tyr ArgSerT

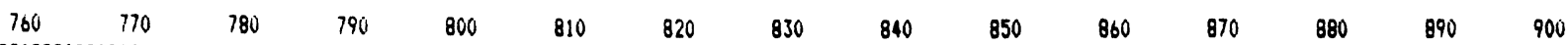

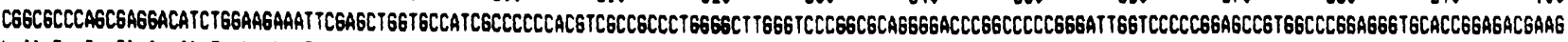

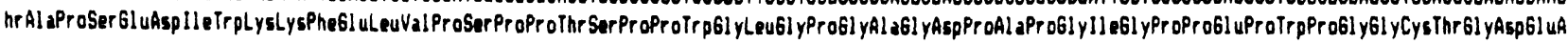

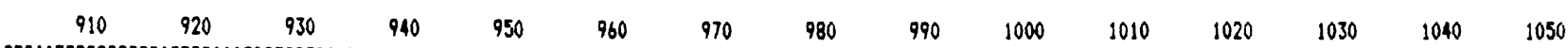

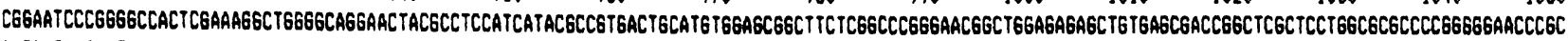

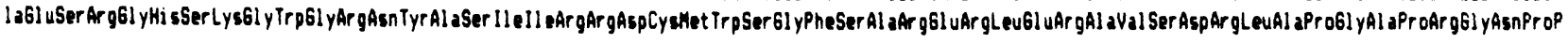

$\begin{array}{llllllllllllll}1060 & 1070 & 1080 & 1090 & 1100 & 1110 & 1120 & 1130 & 1140 & 1150 & 1160 & 1170 & 1190 & 1200\end{array}$

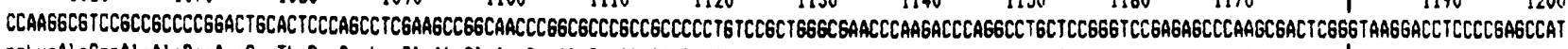

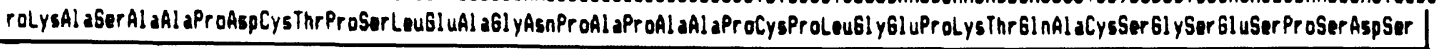

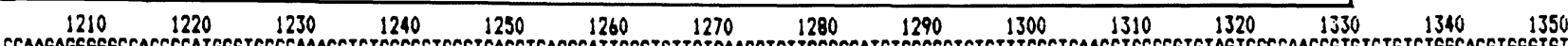
CCAAGAGG 6 GCCACCCCATG6GTGGCCAAAGCTCTSCCCCTSCCTGAGSTCAGGCATTGGCTCTTCTCAAGCTCTTGGGCCATCTCCGCCTCTCTITGGCTGAAGCTGCCCGTGTAGTCCCCAACCGTGTCTGTCTGGCACGTG6GTGT

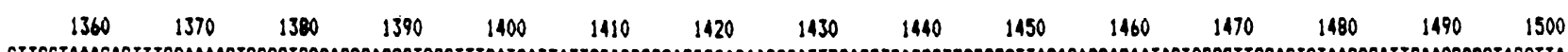

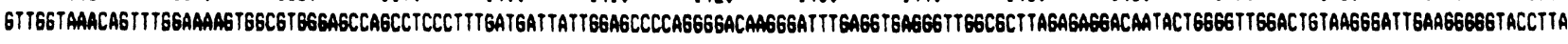
$\begin{array}{lllllllllllllll}1510 & 1520 & 1530 & 1540 & 1550 & 1560 & 1570 & 1580 & 1590 & 1600 & 1610 & 1620 & 1630 & 1640 & 1650\end{array}$

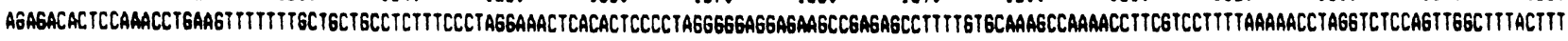

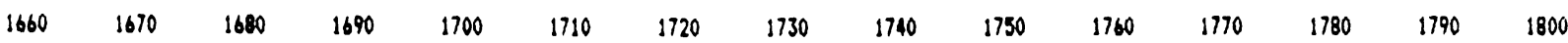

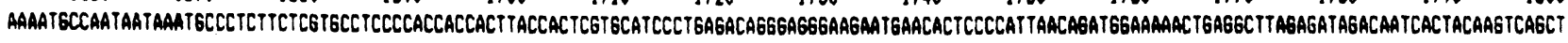

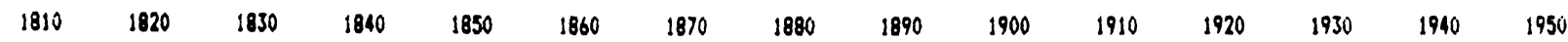
CCAGCTITCTGCCATCTAGCCAGCCCCTCTTCCCCAATGCTCCATCCCAACCAG6CACCTCTTCCTTGATGTTTG6GGTCTT TGW TGGTAGCTTATCTTAGAAGCACTACACCTTGCCTTGCTGTITGTCCTGAGATGGAAAAGTGTCC

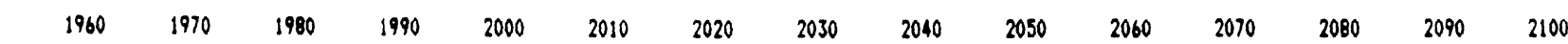
TTCTIGCTCCCCCTCAATAGATCTCCAGCGTCAGCGCTTCCCTGGCATTCAACAAATATTCACTGGCCCCTACTITGTGGCAATCTGTGGGCTACATGCTG6G6TCAAGGCAGTG6AGCTCTAGGCCCTCCTCTCCCATCCTTGATGCAA

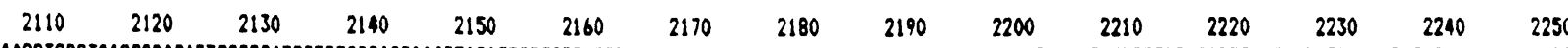

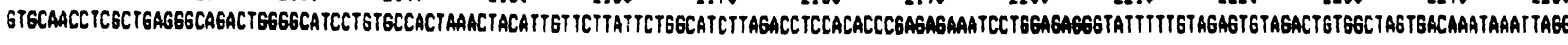
$\begin{array}{lllllllllllll}2260 & 2270 & 2280 & 2290 & 2300 & 2310 & 2320 & 2330 & 2340 & 2350 & 2360 & 2370 & 2380\end{array} 2390 \quad 2400$

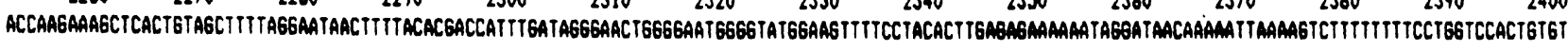

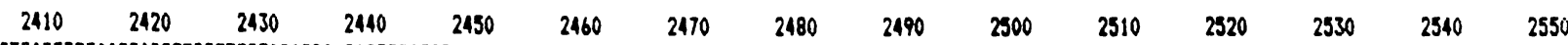

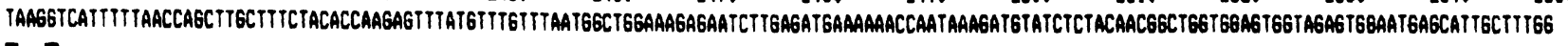

$\left[\begin{array}{lllllllllllll}\text { GAP } & 2560 & 2570 & 2580 & 2590 & 2600 & 2610 & 2620 & 2630 & 2640 & 2650 & 2660 & 2670\end{array}\right.$ [1150 66.

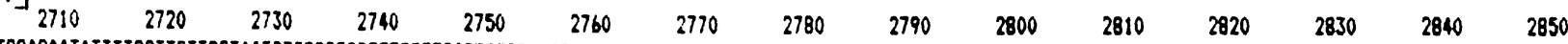

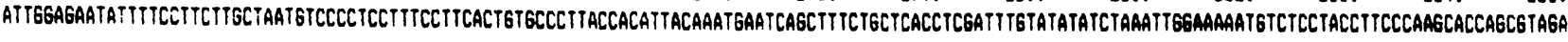

$\begin{array}{llllllllllll}2860 & 2870 \quad 2880 & 2890 & 2900 & 2910 & 2920 & 2930 & 2940 & 2950 \quad 2960 \quad 2970 & 2980 & 2990 & 3000\end{array}$

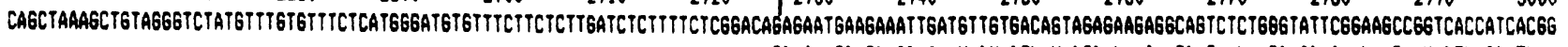

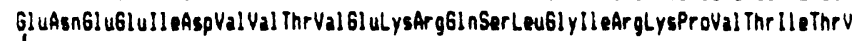

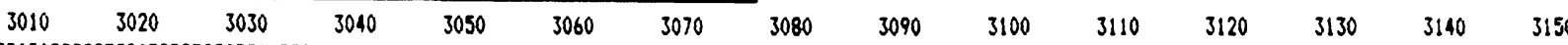

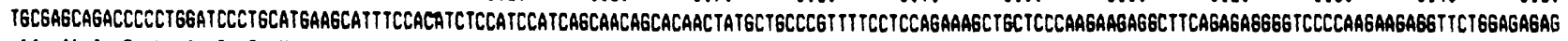

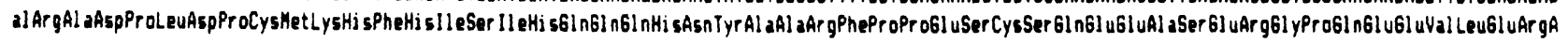

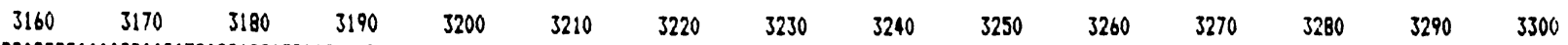

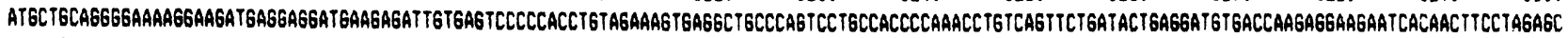

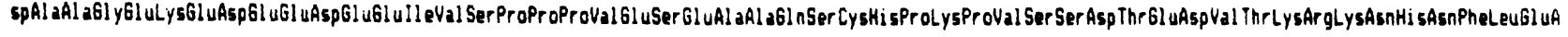

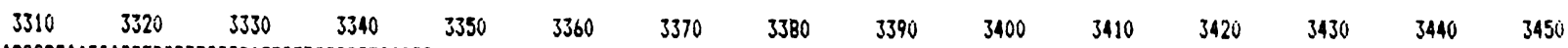
GCAAGAGGCGGAATGACCTGCGTTCGCGATTCTTGGCGCTGAGgGACCAAGTGCCCACCCTGGCCAGCTGCTCCAAGGCCCCCAAAGTAGT6ATCCTAAGCAAGGCCTT6GAATACTTGCAAGCCCTGGT6666GCTGAGAAGAGGATGG

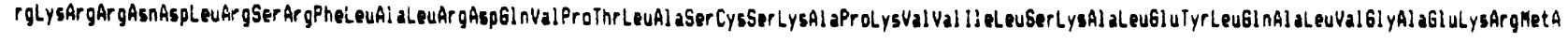

Figure 1. (See page 1315 for legend.) 
DePinho et al.

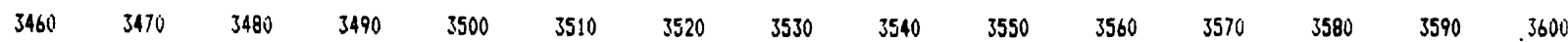

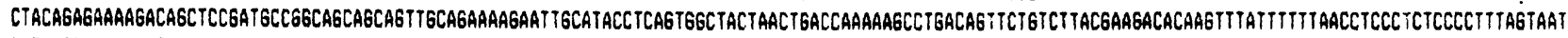

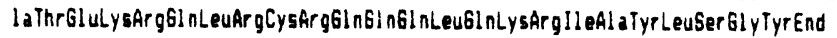

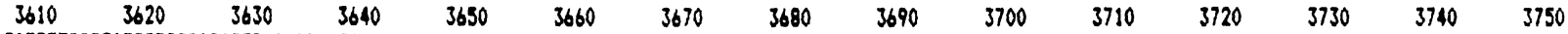

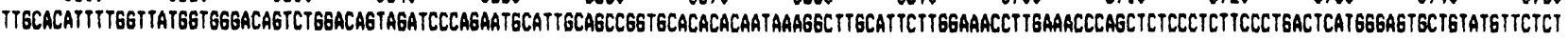

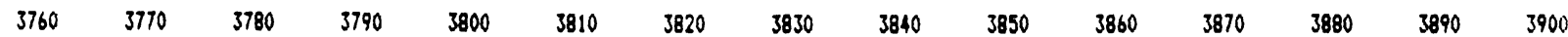

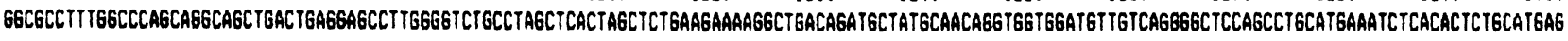

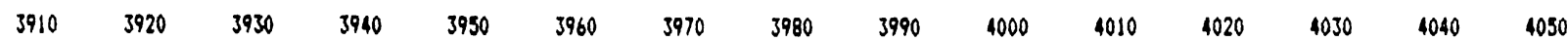

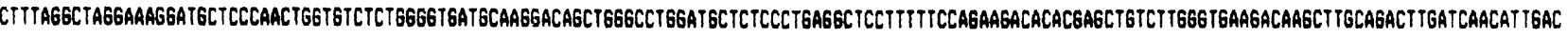

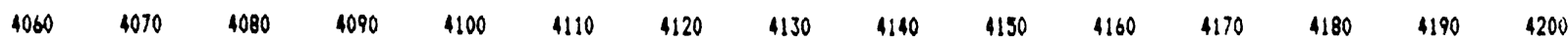

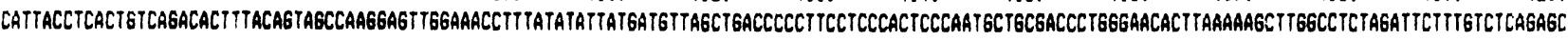

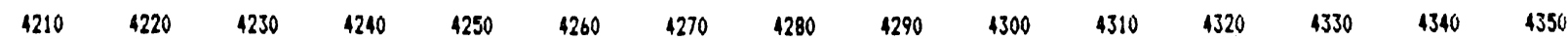

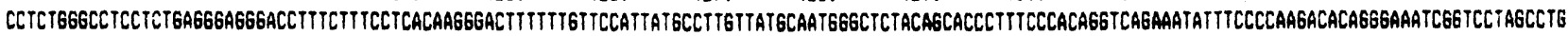

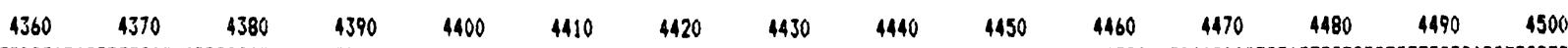

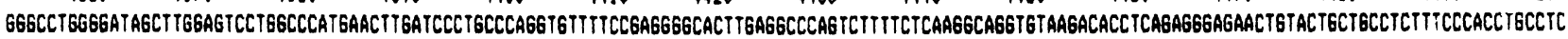

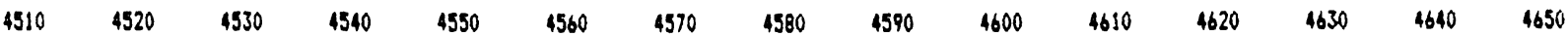
ATCTCAATCCTTGAGCGGCGAGTTTGAAGTTCTTCTGGAACCATGCAAATCTGTCCTCCTCGTGCAATTCCAAGGAGCTTGCTGGCTCTGCAGCCACCCT6GGCCCCTTCCAGCCTGCCATCGCAATCAGATATCTITCCCAGAATCT66

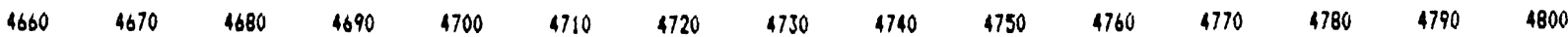

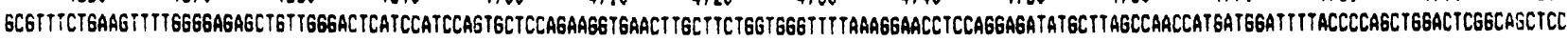

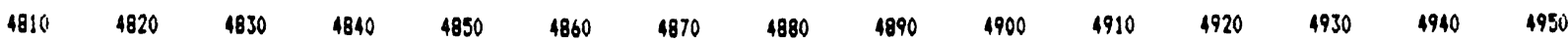

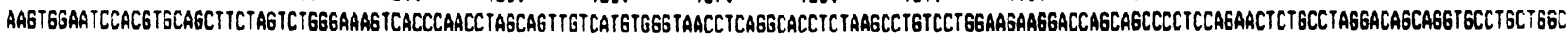

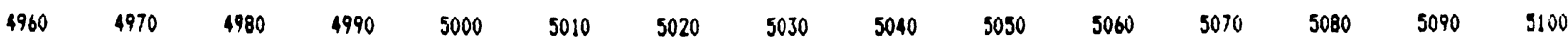

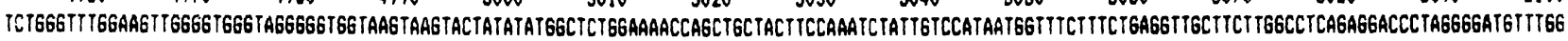

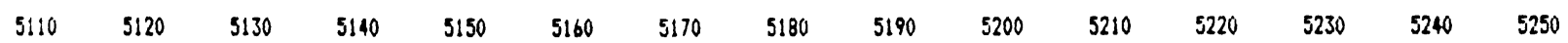

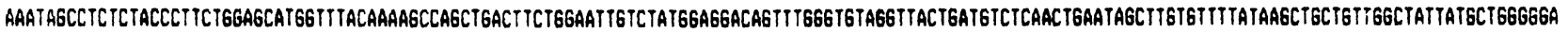

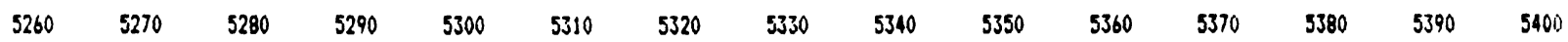

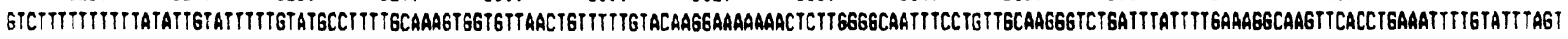

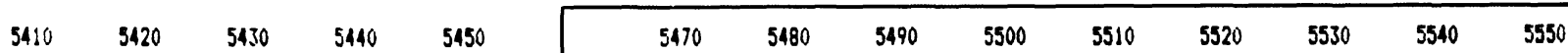

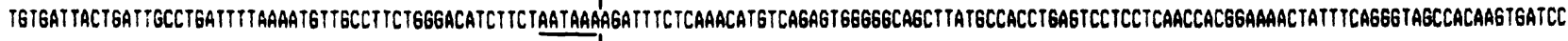

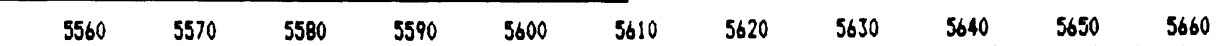

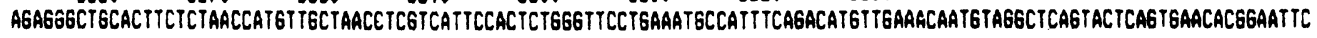

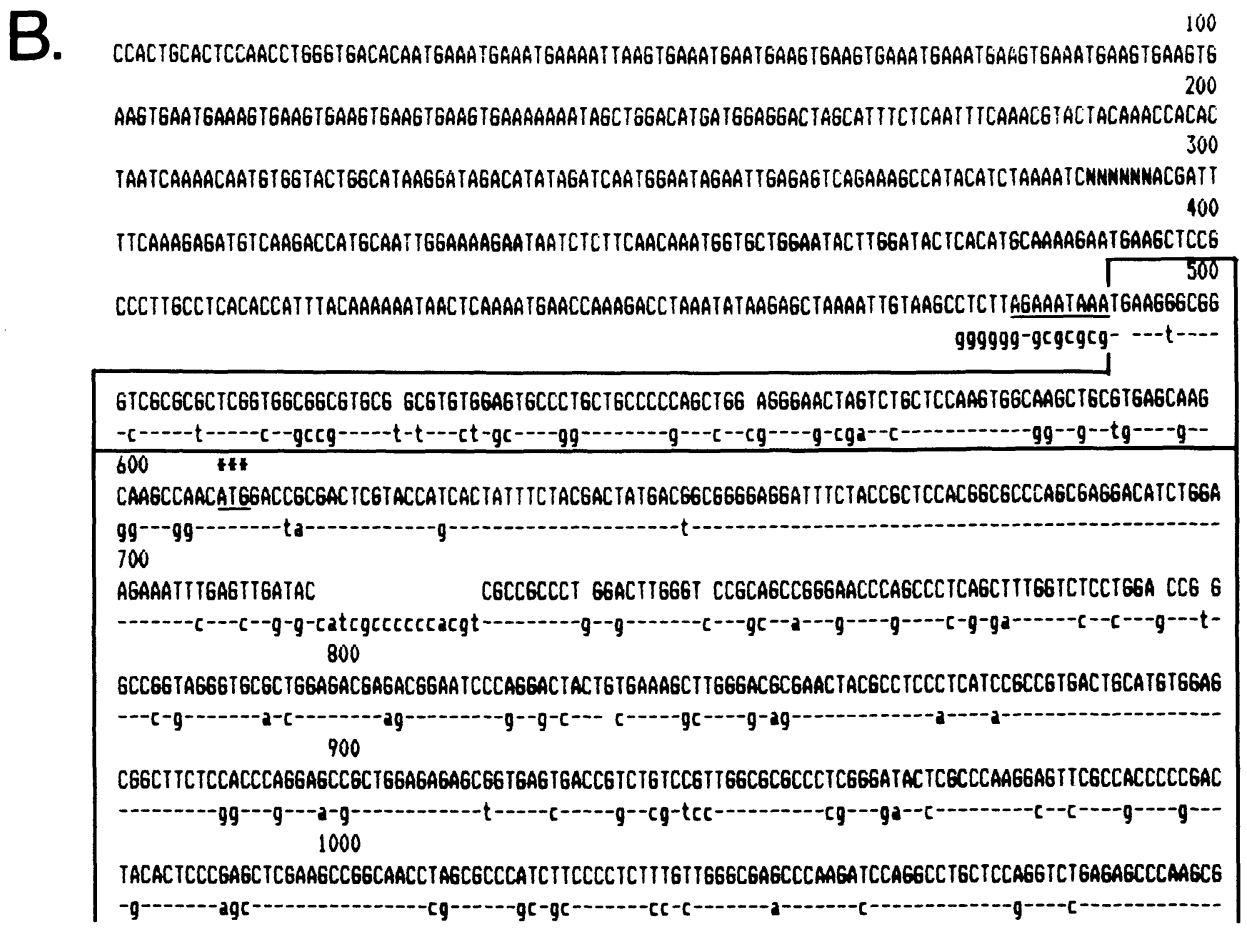

Figure 1. (See facing page for legend.) 


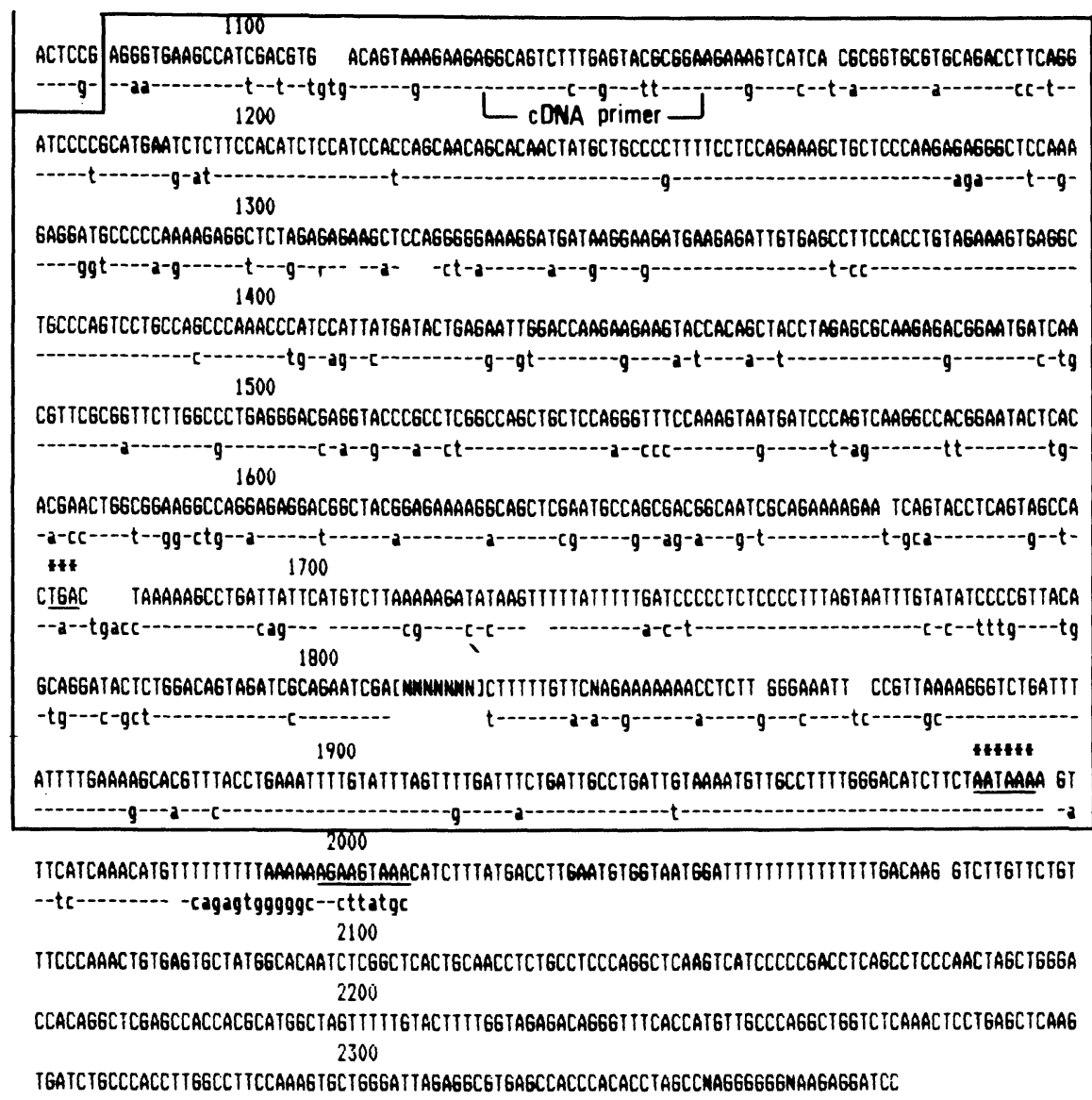
L-MYC CDNA
L-MYC GEMOHIC
L-MYC PSEUDOGENE

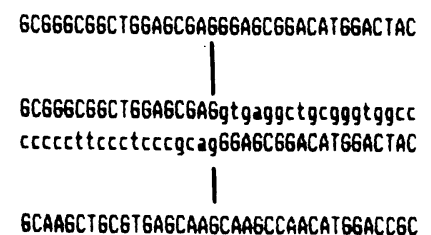

L-MYC CDNA

L-MYC GENOHIC

L-MYC PSEUDOGENE

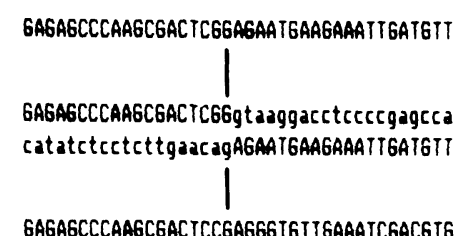

Figure 1. (A) Nucleotide and predicted amino acid sequence of the human L-myc gene. The nucleotide sequence displayed was derived from the L-myc genomic clone R11.1 and was determined by the method of Maxam and Gilbert. Sequencing strategy is outlined in Fig. 2. The $5^{\prime}$ border of homology between the L-myc and L-myc $\psi$ and the $5^{\prime}$ end of the L-myc cDNA clone pPEIII.5 is indicated. The polyadenylation signal is underlined. Boxed areas represent exons. $(B)$ Nucleotide sequence comparison between $L-m y c$ (cDNA) and L-myc $\psi$ genes. The pseudogene sequence is shown in uppercase letters, L-myc cDNA sequence is shown in lowercase letters. The L-myc cDNA sequence was determined in the pPEIII.5 clone, which was derived from the H510 SCLC cell line. The lowercase sequence $3^{\prime}$ to the synthetic oligonucleotide cDNA primer is derived from the R11.1 L-myc genomic sequence. (-) Symbolizes nucleotide homology. At positions $1805-1815$, the series of Ns represents a $2.4-\mathrm{kb}$ region that was not sequenced in the L-myc $\psi$ gene. $(C)$ Nucleotide sequence comparison of the exon-intron boundaries of the pPEIII.5 L-myc cDNA clone, R11.1 L-myc genomic clone, and R1.3 L-myc pseudogene clone sequences (exons $1 / 2=$ upper panel; exons $2 / 3=$ lower panel). Uppercase letters represent exon sequences; lowercase letters represent intron sequences. A vertical line indicates exon boundaries. 

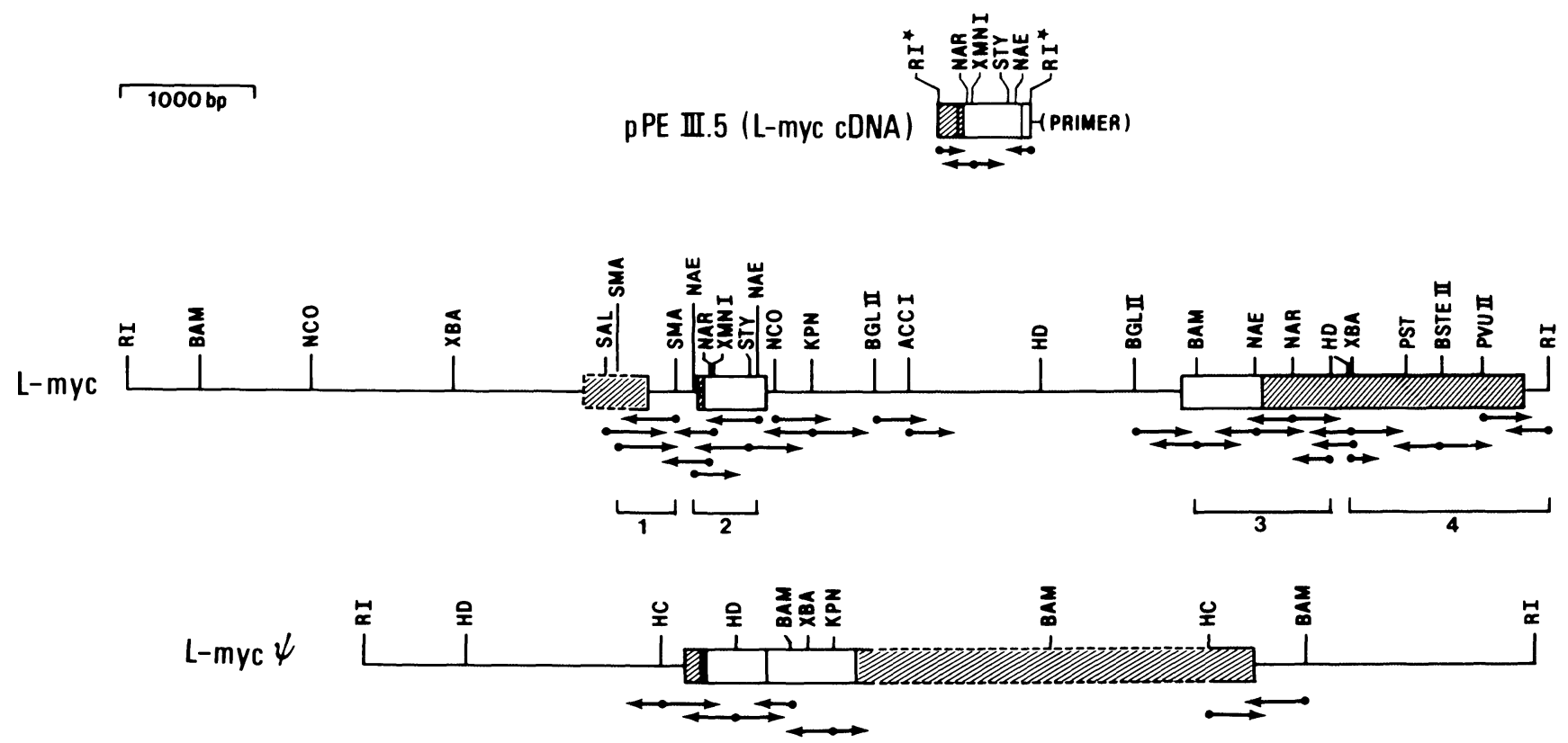

Figure 2. Structure and organization of the L-myc cDNA fragment pPEIII.5; the 10.6-kb L-myc genomic fragment R11.1 and the 8.8-kb L-myc pseudogene genomic fragment R1.3. A partial restriction map indicates restriction endonuclease sites used in the sequence analysis. An asterisk $\left({ }^{*}\right)$ indicates a restriction site created as a result of linker addition during cloning of the cDNA. Horizontal arrows represent sequencing strategy. The boxed areas indicate the position of exons; shaded areas represent untranslated regions, whereas open areas represent putative translated regions. The dashed border of exon 3 in the L-myc pseudogene represents a 2.4-kb region not subjected to nucleotide sequence analysis. Below the restriction map of the L-myc genomic fragment are shown four DNA probes used in screening the L-myc cDNA library. Probe 1 is a 400-bp SmaI fragment encompassing exon 1 and a portion of intron 1. Probe 2 is a 450-bp Nael fragment that contains exon 2. Probe 3 is a 1200 -bp BamHI-HindIII fragment containing exon 3 translated sequences. Probe 4 is a $1500-b p X b a I-E c o R I$ fragment containing only 3 ' untranslated sequences.

L-myc sequence with the $3^{\prime}$ termini of the mouse L-myc cDNA (Legouy et al. 1987) and the L-myc $\psi$ gene. A consensus polyadenylation sequence motif AATAAA (Proudfoot and Brownlee 1976) occurs at corresponding locations in all the L-myc genes and is followed by a poly(A) stretch in the mouse L-myc cDNA and the L-myc $\psi$ (Fig. 1A,B). Thus, at least one form of the human L-myc gene consists of a three-exon organization similar to that of the c- and N-myc genes (Fig. 2): exon 1 is about $170 \mathrm{bp}$ in length; exon 2 is $505 \mathrm{bp}$; and exon 3 is $2529 \mathrm{bp}$. The combined size of these sequences, including a poly $(\mathrm{A})$ stretch of variable length, is approximately $3.5 \mathrm{~kb}$; this length could account for the size of the largest noted human L-myc mRNA sequence ( 3.5-3.8 kb), which appears to represent a major form of the L-myc mRNA (Nau et al. 1986; Fig. 5).

A long open reading frame (ORF) in the L-myc gene begins with an ATG codon at position 684 (9 bp downstream from the 5 ' boundary of exon 2) and extends 1092 nucleotides to an in-phase terminator at position 3522 in exon 3. Multiple termination codons are present in the other two reading frames. If we assign the first ATG of this ORF as coding for the amino terminal residue of the protein, L-myc would consist of 364 amino acids with a predicted molecular weight of approximately 38 $\mathrm{kD}$. Recent evidence has indicated the possibility that translation initiation of the c-myc mRNA can occur at nonmethionine residues within exon 1 (King et al.
1987); such upstream initiation could theoretically extend the amino terminus of the L-myc coding domain an additional 38 or 160 amino acids (in the presence or absence of first intron splicing, respectively) before an inphase termination codon would be reached at position 202 in exon 1.

The increased size of the L-myc mRNA relative to Nand c-myc appears to result primarily from its larger $3^{\prime}$ untranslated region - 1900 bp compared with 900 bp for $\mathrm{N}-m y c$ (Kohl et al. 1986; DePinho et al. 1986; Stanton et al. 1986) and 350 bp for c-myc (Battey et al. 1982; Bernard et al. 1983). Similar to c-myc (Bernard et al. 1983) and N-myc (DePinho et al. 1986), the 5' and 3' untranslated regions of the L-myc mRNA exhibit about $80 \%$ nucleotide sequence conservation between the mouse and human genes (Fig. 3). This degree of homology is comparable to that seen in the translated regions (data not shown). While the untranslated regions of the individual $\mathrm{c}^{-}, \mathrm{N}-$, and $\mathrm{L}-\mathrm{myc}$ genes are conserved across species, the untranslated regions of each type of myc gene diverge extensively from one another (data not shown).

\section{myc family gene products are highly related}

The putative human and mouse L-myc proteins contain 364 and 368 amino acids, respectively (Fig. 4B). Allowing for the four-amino-acid insertion near the $5^{\prime}$ border of 


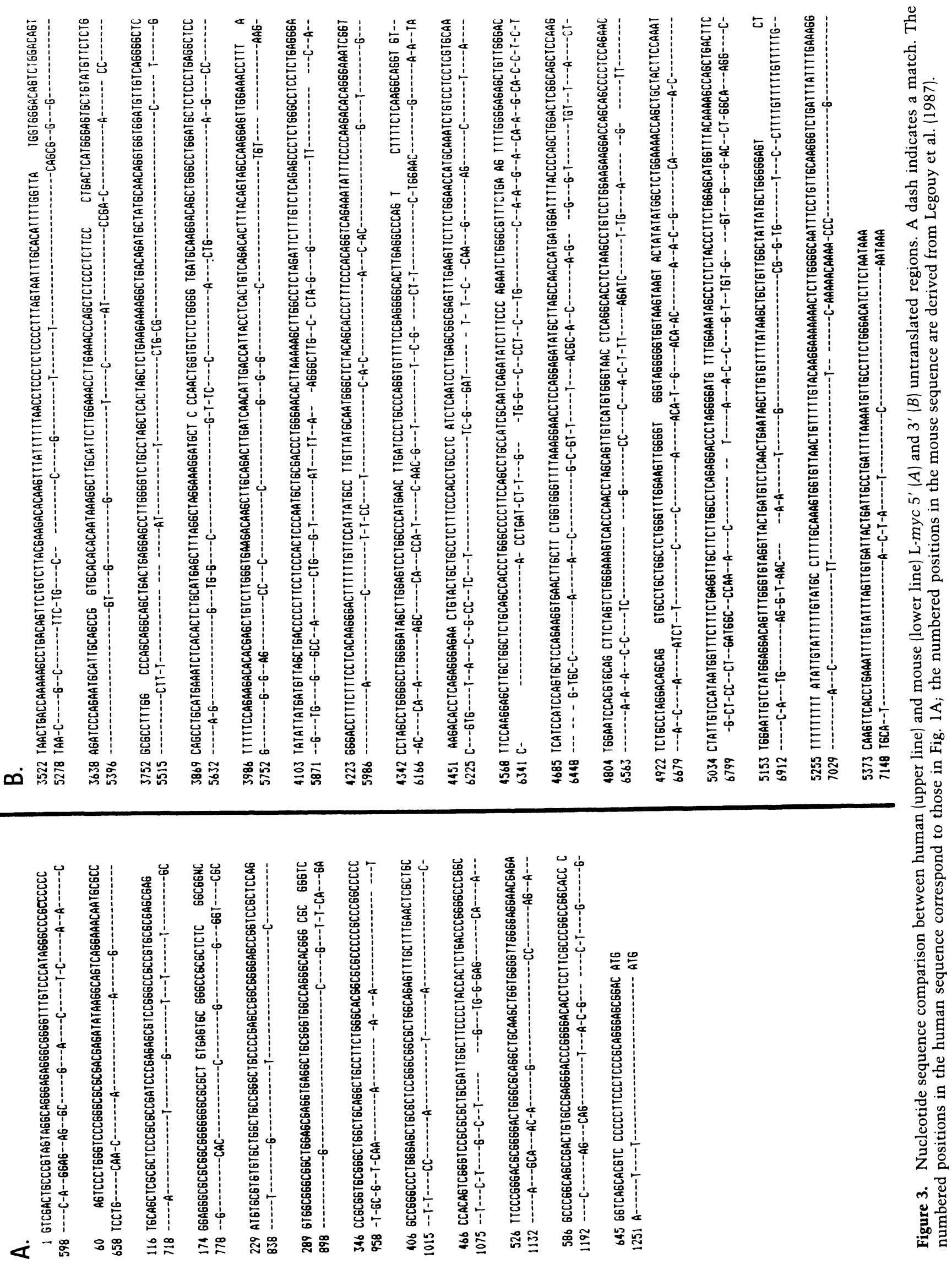


A.
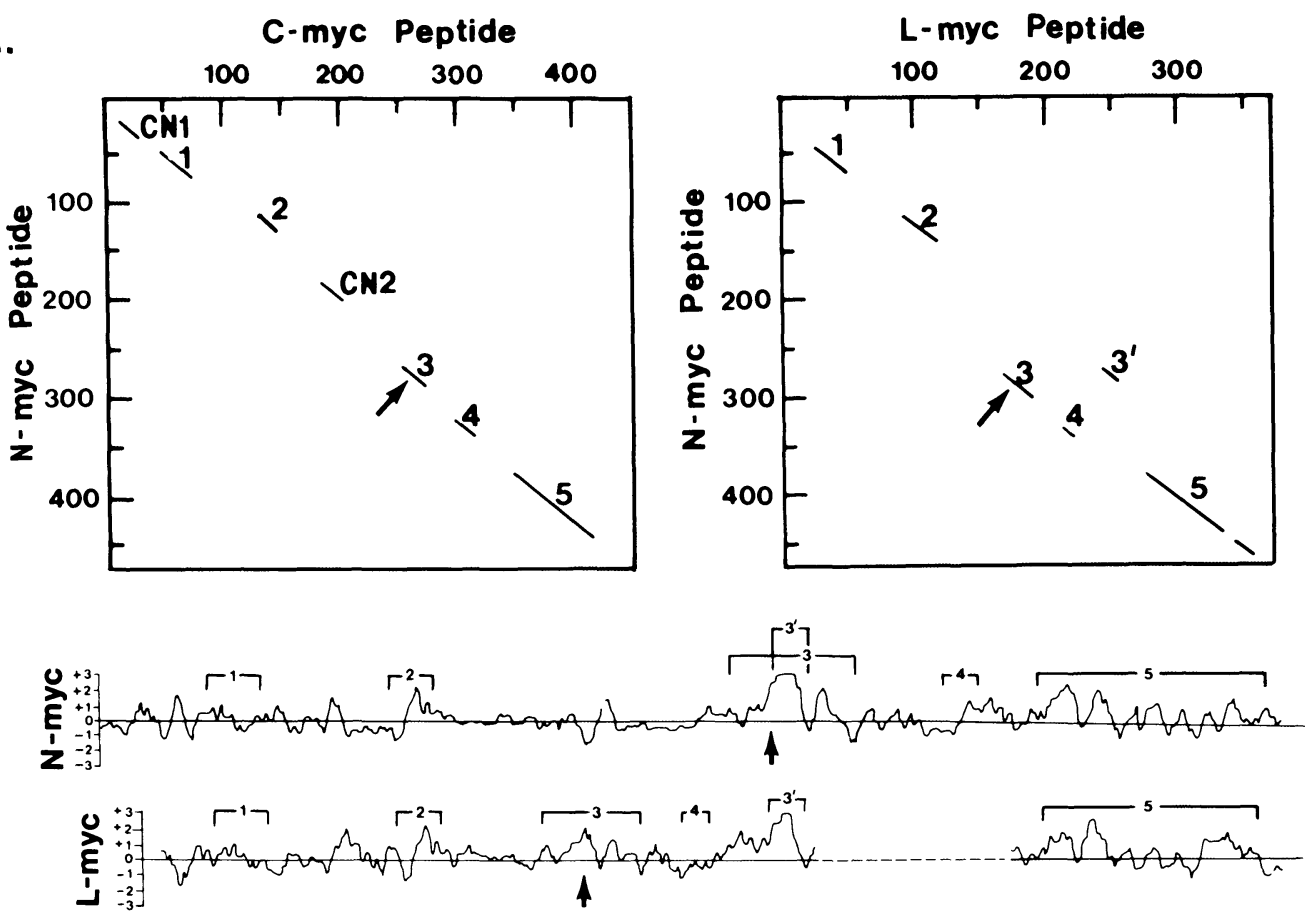

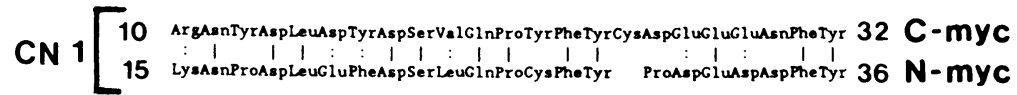

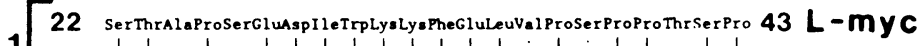

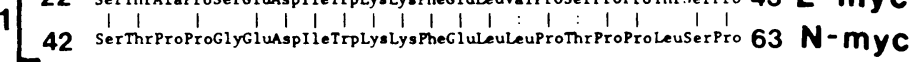

$$
\begin{aligned}
& 293 \text { Aspcysmeti rpSerGlypheSerAl aAr gGluargleugluargaleval Seraspargleu } 113 \mathrm{~L}-\mathrm{m} \text { yC } \\
& 2114 \text { aspcysmettrpserclypheseralaArgGiuLysLeugluargalaval SerciulysLeu } 134 \mathbf{N} \text {-myC }
\end{aligned}
$$

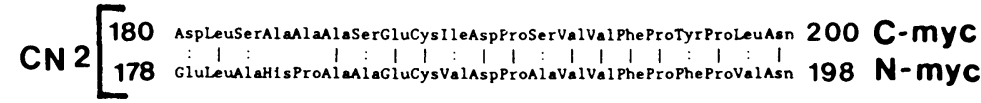
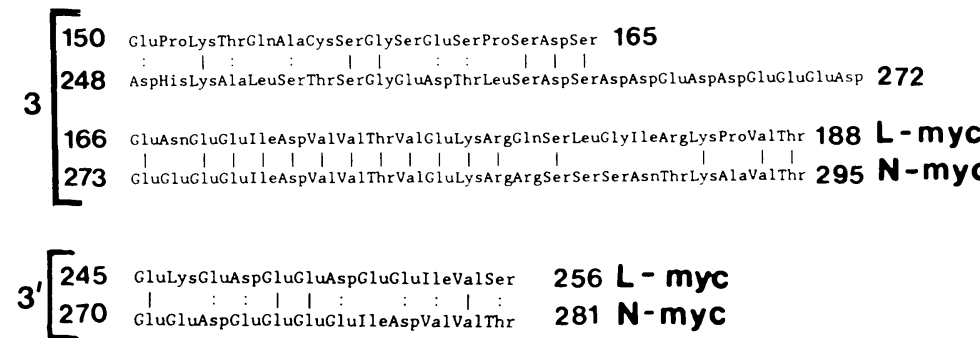

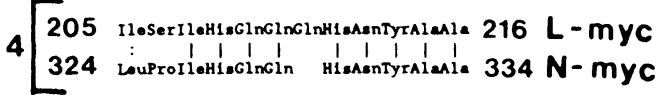

$$
\begin{aligned}
& 277 \text { ProLyspro valsor SerAsp ThrGlunspValThrLysarglysasnH1sAenFhe }
\end{aligned}
$$

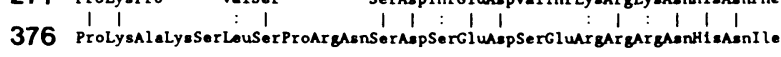

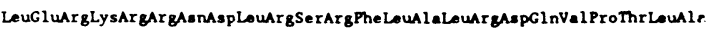

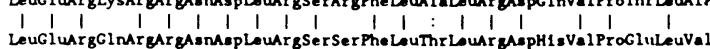

$$
\begin{aligned}
& \text { SerCysSerLysAlaProLysvalVall leLeuSerLysAlaLeuGluTyrLouGlnAlaLeuValglyAle }
\end{aligned}
$$

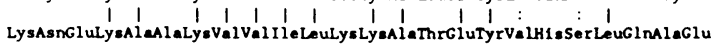

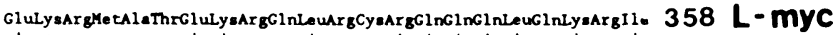

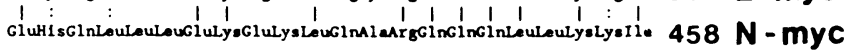$$
5
$$

Figure 4. (See facing page for legend.) 


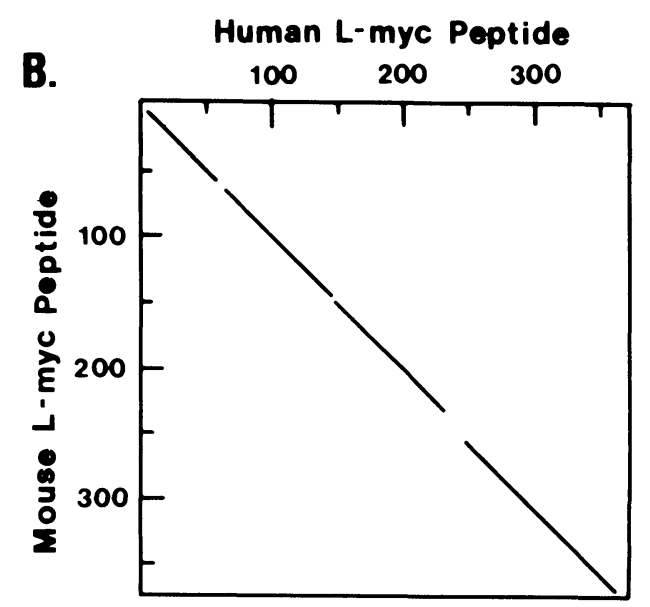

1 MetAspTyrAspSerTyrGlnHisTyrPheTyrAspTyrAspCysGlyGluAsp PheTyr

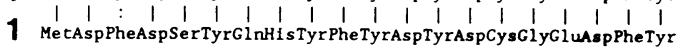
ArgSerThralaProSerGluAspI leTrpLys Lys PheGluLeuVal ProSerProPro ArgSerThralaProsergluaspI leTrpLysLysPhegluLeuval I I I I I ThrSerProProTrpGlyLeuGlyProGlyAlaGl yaspProAlaProGlyI leGlyPro

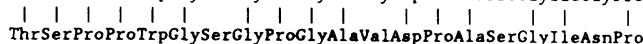
ProGluProTrpProGlyGlyCysThrGlyAspGluAlaGluSerArgGlyHisSerLys

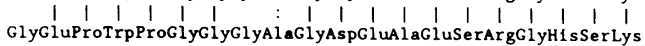
GlyTrpGlyArgAsnTyrAlaSerI leI leArgArgAspCysMetTrpSerGlyPheSer

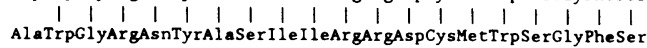
Al aArgGluArgLeuGluArgAlaValSerAspargLeuAl aProGlyAlaProArgGly

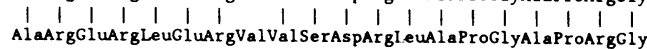
AsnProProLysalaSerAlaAlaProAspCys ThrProSerLeuGluAlaGlyAsnPro

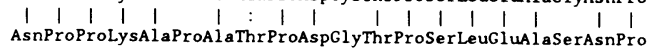
AlaProAlaAlaProCysProLeuGlyGluProLysThrGlnAlaCysSerGlySerGlu

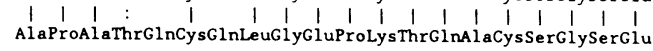
SerProSerAspSerGluAsnGluGluI leAspValValThrValGluLysArgGlnSer

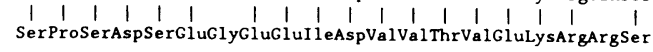
LeuGlyIleArgLys ProValThrI leThrValArgAl aAspProLeuAspProCysMet

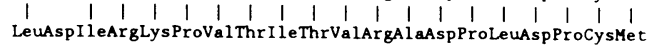
LysHisPheHisIleSerIleHisGlnGlnGlnHisAsnTyrAlaAlaArgPheProPro

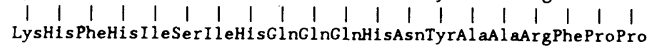
GluSerCysSerGlnGluGluAlaSerGluArgGlyProGlnGluGluVal Leu

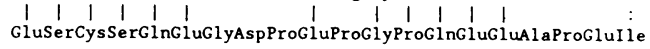
Glu ArgAspalaAlaGlyGluLysGluAspGluGluAspGlugluIleValser

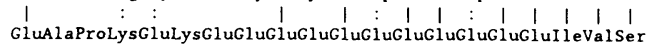
ProProProValGluSerGluAlaAlaGlnSerCysHis ProLysProValSerSerAsp

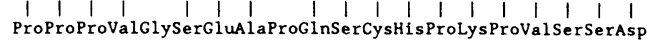
LeuArgSerArgPheLeuAlaLeuArgAspGInValProThrLeuAlaSerCysSerLys LeuArgSerArgPheLeuAl aLeuArgaspGinVal ProThrLeuAlaSerCysSerLys AlaProLysValVal IleLeuSerLysAlaLeuGluTyrLeuGInAlaLeuValGlyala AlaproLysvalvalileleuSerlysalaLeugluTyrLeuGinalaLeuvalgiyala GluLysArgMetAl aThrGluLysArgGlnLeuArgCysArgGlnGlnGlnLeuGlnLys

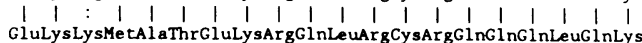
ArgIleAlaTyrLeuSerGlyTyrEnd 364 Human L-myc

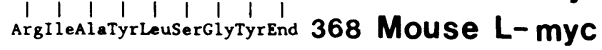

exon 3 in the mouse sequence, the overall homology between mouse and human L-myc proteins is $90 \%$ with half of the changes representing conservative amino acid substitutions (Fig. 4B). The predicted size of the L-myc protein is significantly smaller than that of the observed size of human c-myc (Battey et al. 1983; Bernard et al. 1983) or N-myc (Kohl et al. 1986; Stanton et al. 1986) proteins which measure 439 and 464 amino acids, respectively.

Several observations indicate that the proposed L-myc coding region is correct. Detailed comparisons reveal clusters of amino acids that are highly conserved among the three myc proteins. Dot matrix comparison of the human $\mathrm{N}-m y c$ and $c-m y c$ proteins identifies seven clusters of highly conserved amino acids (Fig. 4A, top, first panel). The L-myc protein possesses five of these homology regions which are interspersed between divergent regions and which span the entire length of the proteins (Fig. 4A, top, second panel). One of these five common homology regions (region 3 ) is encoded by sequences that span the exon 2-exon 3 splice junctions of all three proteins (Fig. 4); the shorter size of the L-myc protein appears to result from the absence of approximately 80 (mostly nonconserved) amino acid residues found within exon 2 between homology regions 2 and 3 of $\mathrm{c}$ - and $\mathrm{N}-\mathrm{myc}$ (Fig. 4). The latter alteration occurs in a region previously noted to be subject to structural variations between myc-related proteins (Ralston and Bishop 1983; Kohl et al. 1986). Hydropathy plots also demonstrate considerable relatedness among c-myc, N-myc, and L-myc. N-myc and c-myc plots are virtually superimposable (data not shown); and N-myc and L-myc have a highly related pattern (Fig. 4A, middle). However, the truncated length of L-myc exon results in closer positioning of homology regions 3 and 4 relative to regions 1 and 2. In this regard, a portion of L-myc homology region 3 appears to be missing a major internal stretch of acidic polyglutamic/aspartic acid residues (termed homology region $3^{\prime}$; Fig. 4A); of potential significance, such an acidic stretch is encoded by sequence further downstream within exon 3 of the L-myc gene. This potential transposition of coding sequences results in the conservation of the spatial relationship within the L-myc protein of this highly acidic amino acid cluster and L-myc

Figure 4. $(A)(T o p)$ Dot matrix computer analysis of protein sequence homology between human $\mathrm{N}-m y c$ and human c-myc (left panel) and human N-myc and L-myc (right panel) was performed with a window of 8 and a stringency of $60 \%$. Regions of homology $(\mathrm{CN} 1, \mathrm{CN} 2,1-5)$ are indicated. An arrow denotes the position of the exon 2-3 exon splice junction. (Middle) Hydrophobic $(-)$ and hydrophilic $(+)$ residues are plotted across the length of the peptide and assigned a hydropathy value, ranging from -3 to +3 , as determined by the method of Hopp and Woods (1981). (Bottom) The amino acid sequence of homology regions between $\mathrm{c}^{-}, \mathrm{N}-$, and $\mathrm{L}-m y c$ proteins is shown. A solid vertical line indicates identity between residues; a double dot indicates a conservative amino acid substitution. $(B)$ Dot matrix analysis of protein sequence homology between the mouse and human L-myc protein was performed using a window of 20 and stringency of $90 \%$. Solid vertical lines indicate identity; a double dot indicates a conservative substitution. 
homology regions 1 and 2, thereby maintaining the position of these residues along the L-myc peptide backbone relative to their position in the $\mathrm{N}$ - and c-myc proteins (Fig. 4A, top and middle).

In recent studies, in vitro mutagenesis analyses of the human c-myc gene uncovered a number of regions that appear essential for nuclear targeting, nuclear localization, and transformation activity (Stone et al. 1987). Comparison of these regions among the $\mathrm{c}_{-}, \mathrm{N}-$, and L-myc proteins demonstrates areas of strong conservation (for summary, see Alt et al. 1987). Gene fusion studies have demonstrated that c-myc residues 351-381 are capable of directing the movement of cytoplasmic pyruvate kinase to the nucleus (Stone et al. 1987). There is $70 \%$ conservation within this region among all myc proteins. Other studies demonstrate that $\mathrm{c}-\mathrm{myc}$ residues 106-143 and 371-412 appear necessary for retention within the nucleus, as opposed to targeting (Stone et al. 1987). Both of these domains are also highly conserved among all myc proteins. It is notable that within these coordinates there are residues that are identical in the three proteins (e.g., c-myc residues $132-140$ are the same as L-myc residues $93-101$ and $\mathrm{N}-m y c$ residues $113-120)$.

\section{$L$-myc can cooperate with ras to transform normal cells} in culture

L-myc gene amplification occurs in a subset of human SCLC (Nau et al. 1985). By analogy to N-myc gene amplification in human neuroblastomas (Kohl et al. 1983; Schwab et al. 1983|, the increased expression of L-myc as a result of gene amplification may confer an increased growth potential to malignant cells. The c-myc (Land et al. 1983) and N-myc (Schwab et al. 1985; Yancopoulos et al. 1985) genes possess similar transforming activities in the rat embryo fibroblast (REF) cotransformation assay. Therefore, to assay the oncogenic potential of the L-myc gene and the L-myc $\psi$ gene, we tested their ability to cooperate with an activated Ha-ras gene to transform early-passage REFs in culture. The 10.6-kb EcoRI fragment containing the L-myc gene and the 8.8-kb EcoRI fragment containing the L-myc $\psi$ gene were subcloned into a retroviral expression construct, $\mathrm{pV} \cos 7$ (Table 1, bottom); the L-myc fragment was inserted in both orientations relative to the transcriptional orientation of two Moloney murine leukemia virus long terminal repeats (LTRs). The L-myc $\psi$ gene was subcloned only in the same orientation as the Moloney promoter. These constructs were cotransfected with and without the mutant Ha-ras gene into early-passage rat embryo fibroblasts.

$\mathrm{L}-m y c$ constructs that contained the L-myc gene in the same transcriptional orientation as the flanking LTRs (pL-myc-S) were not able to transform REFs alone but did cooperate with a mutant Ha-ras gene. In the c-, $\mathrm{N}-$, and L-myc/ras cotransfections, dense foci became noticeable 7-15 days after the transfection. Foci consisted of individual cells with clearly transformed morphology, rapidly overgrowing and displacing the normal monolayer. The frequency of focus formation in the various L-myc/ras cotransformations was significantly greater than the focus formation observed in the $\mathrm{pV} \cos 7 /$ ras or ras alone controls but was significantly less than the positive cotransfection controls, c-myc/ras and $\mathrm{N}$-myc/ras (Table 1). The L-myc gene in the same transcriptional orientation as the LTRs cotransfected with ras exhibited the greatest efficiency of transformation (Table 1 ; pVL-myc/ras; $p<0.001$ ). The L-myc gene in the opposite transcriptional orientation (pVL-myc-AS) and the L-myc gene without neighboring LTRs (pL-myc) also cooperate with ras to induce transformation at a significant efficiency above background controls (Table 1; pVL-myc-AS, $p \leqq 0.01$; pL-myc, $p \leqq 0.05)$, but the efficiency was somewhat less than the pVL-myc-S/ras combination. L-myc also conferred upon the transformants a high frequency of anchorage-independent growth and tumorigenic potential in young syngeneic hosts (Table 1).

Analysis of DNA prepared from the transformed REF lines demonstrated the presence of multiple copies of the introduced ras and myc genes (data not shown). Total RNAs prepared from REF transformants and con trols were screened for expression of the introduced oncogenes. All of the REF transformants expressed high levels of the introduced ras gene (Fig. 5, middle panel). $\mathrm{L}-m y c$ expression could be detected only in permanent REF lines transformed with the various L-myc/ras combinations (Fig. 5, bottom panel). The range of L-myc expression varied in each of the L-myc/ras transformants but greatly exceeded the level of L-myc expression seen in normal developing tissues and approached the levels seen in L-myc-expressing SCLC. pL-myc/ras transformants expressed an approximately 10- to 20 -fold lower amount of normal L-myc message than the pVL-myc-S/ ras cell lines (Fig. 5, bottom panel). L-myc expression levels in tumors derived by injecting transformed REF lines into syngeneic hosts were similar to those observed in the corresponding cultured cell lines /data not shown). Total cellular RNA derived from pVL-myc-AS/ ras transformants was also assayed with SP65-generated $\mathrm{L}-m y c$ antisense and sense probes and found to express normal-sized L-myc message (data not shown).

Total RNAs derived from the L-myc/ras transformants contain L-myc-hybridizing sequences of 3.8, 2.2, and $1.8 \mathrm{~kb}$; sequences of the same size are found in the total RNA of the H510 SCLC (Fig. 5, lower panel) and in human L-myc-expressing embryonic tissues (R. DePinho and F. Alt, unpubl.). L-myc/ras transformants also exhibited a 5.0-kb transcript that initiates from the viral promoter (Fig. 5, lower panel). The presence of normalsized L-myc message in each of the L-myc/ras transformants, including the antisense construct, indicates that $\mathrm{L}-m y c$ promoter elements sufficient for expression in REF lines are contained in the 10.6-kb L-myc clone. ras alone transformants did not express L-myc (Fig. 5, panel C).

$L$-myc $\psi$ is a processed L-myc pseudogene

The genomic organization of the L-myc $\psi$ gene corre- 
Table 1. Transformation of REFs with myc-family and ras gene combinations

\begin{tabular}{|c|c|c|c|c|c|}
\hline \multirow[b]{2}{*}{ Transfected DNA } & \multicolumn{3}{|c|}{$\begin{array}{c}\text { Plates with transformed } \\
\text { foci/total plates }\end{array}$} & \multirow{2}{*}{$\begin{array}{l}\text { Growth in soft agar, } \\
\text { lines positive/ } \\
\text { lines tested }\end{array}$} & \multirow{2}{*}{$\begin{array}{l}\text { Tumorigenicity, } \\
\text { rats with tumors } \\
\text { injected }\end{array}$} \\
\hline & Exp. 1 & Exp. 2 & Exp. 3 & & \\
\hline pkomyc + T24-ras & $9 / 12$ & $9 / 9$ & 9/9 & $2 / 2$ & $2 / 2$ \\
\hline $\mathrm{pV}-\mathrm{Nmyc}+\mathrm{T} 24-r a s$ & - & $12 / 16$ & $8 / 12$ & - & - \\
\hline pV-Lmyc-S + T24-ras & $6 / 11$ & $16 / 36$ & $17 / 36$ & $3 / 4$ & $9 / 9$ \\
\hline pV-Lmyc-AS + T24-ras & $6 / 11$ & - & $7 / 18$ & $4 / 4$ & $2 / 5$ \\
\hline $\mathrm{pL}-m y c+\mathrm{T} 24-r a s$ & $3 / 11$ & - & $4 / 15$ & $2 / 2$ & $4 / 4$ \\
\hline $\mathrm{pL}-m y c \psi-\mathrm{S}+\mathrm{T} 24-r a s$ & $0 / 12$ & - & $1 / 12$ & - & - \\
\hline $\mathrm{pV} \cos -7+\mathrm{T} 24-$ ras & - & $0 / 12$ & $2 / 12$ & $1 / 2$ & $1 / 2$ \\
\hline pV-Lmyc-S & $0 / 12$ & - & $0 / 12$ & - & - \\
\hline T24-ras & $0 / 12$ & $0 / 9$ & $2 / 12$ & $0 / 2$ & $0 / 2$ \\
\hline \multirow[t]{5}{*}{ None } & - & - & - & $0 / 2$ & $0 / 3$ \\
\hline & $\stackrel{1000 \mathrm{~b}}{\longrightarrow}$ & & & & \\
\hline & & & $\stackrel{H}{\sim}$ & $p L-m y c \psi-S$ & \\
\hline & $\stackrel{H}{x}$ & & & $p V-L m y c-S$ & \\
\hline & $\underset{\infty}{\infty}$ & & . & $p V-$ Lmyc-AS & \\
\hline
\end{tabular}

The data for the first three columns are presented as the number of plates with positive foci compared to the total number of plates into which each particular transfection was finally divided; due to the way the cells were passaged after transfection, each plate in the final passage has independent transformants. At 2 weeks after transfection each positive plate had $1-5$ foci, whereas at 4 weeks each positive plate had 5-20 foci; presumably some of these were due to metastases. Cell lines derived from c-myc/ras foci (two lines examined) or L-myc/ras foci (four lines examined) were assayed for both colony formation in soft agar and the ability to cause tumors in young syngeneic rats; each line assayed for tumorigenicity was injected in two rats. As a nontransfected control for these assays (bottom line) we used REFs propagated in culture. Both the colonies in soft agar and the tumors in the rats appeared and grew at approximately the same rate for either the L-myc/ras or c-myc/ras transformants. These tumors were noted in all cases within 1 week of cell injection, grew rapidly, and resulted in the death of the host animal within 2-3 weeks.

The L-myc pVcos7 expression constructs are shown below the table. L-myc and L-myc $\psi$ inserts were subcloned between two directly repeated Moloney leukemia virus LTR sequences in the transcriptional orientation shown. pVL-myc-S and pVL-myc-AS constructs contained the L-myc gene in the same or opposite transcriptional orientation as the flanking LTRs, respectively. pL-myc construct contained the L-myc subcloned into the pUC18 plasmid vector and did not contain neighboring LTR sequences. pVL-myc $\psi$-S contained the L-myc $\psi$ gene in the same transcriptional orientation as the flanking LTRs. pT24-ras construct contains the 6.2-kb BamHI insert harboring the activated (Val-12) human H-ras oncogene.

sponds to the structure of the L-myc cDNA (Figs. 1B and 2). The L-myc $\psi$ gene contains initiation and termination codons in the same relative positions as the L-myc gene; however, the L-myc $\psi$ gene contains numerous inphase termination codons due to insertions and deletions that result in frameshift mutations. Nucleotide sequence homology between L-myc transcribed regions and the corresponding L-myc $\psi$ regions is approximately $90 \%$. However, restriction map comparisons between the L-myc $\psi$ and L-myc $3^{\prime}$ untranslated regions reveal that the L-myc $\psi$ gene contains an additional $850 \mathrm{bp}$ within the 2.4-kb region not subjected to direct nucleotide sequence analysis (Fig. 1B, 2.4-kb region is indicated as a series of Ns) and suggests that the L-myc $\psi$ gene has undergone extensive alterations in this region (Fig. 2, dashed portion of exon 3). A consensus polyadenylation signal is followed by a small poly(A) stretch starting at position 1991 which does not exist in the L-myc 3'flanking sequence. Immediately flanking the poly(A) tract, there exists a 9-bp sequence that is directly repeated precisely $5^{\prime}$ to where the $5^{\prime}$ homology between the L-myc and L-myc $\psi$ ceases. The repeat sequences, AGAAATAAA and AGAAGTAAA occur at positions 482 and 1996, respectively. Direct repeats are a sequence motif common to many processed pseudogenes and may be related to the mechanism(s) responsible for pseudogene reintegration in the genome (for review, see Vanin 1984). The L-myc $\psi$ gene does not exist in the mouse genome (data not shown) and does not function in the cotransformation assay (see above). Thus, the L-myc $\psi$ gene appears to possess all of the structural features of a processed pseudogene: It is a processed, nonfunctional 
Figure 5. Expression of introduced ras and myc genes in the transfected REF cell lines. Ten micrograms of total RNA, prepared from indicated lines, was used in each lane. REF refers to RNA isolated from normal rat einbryo fibroblasts. H510 refers to RNA isolated from a human SCLC. All of the L-myc/ras transformants listed in Table 1 expressed the introduced L-myc construct (not shown); the highest and lowest L-myc-expressing transformants are shown. Duplicate filters were probed with a ${ }^{32} \mathrm{P}$-labeled 500-bp PstI fragment containing the human c-myc exon $2|A|$, a $1.6-\mathrm{kb}$ HindIII fragment containing the Ha-ras gene $|B|$, or a 450 bp Nael fragment containing human L-myc exon 2. The introduced c-myc gene was driven from the simian virus 40 promoter linked upstream to the second exon, therefore c-myc RNA expressed from the construct is smaller than the normal endogenous c-myc mRNA.

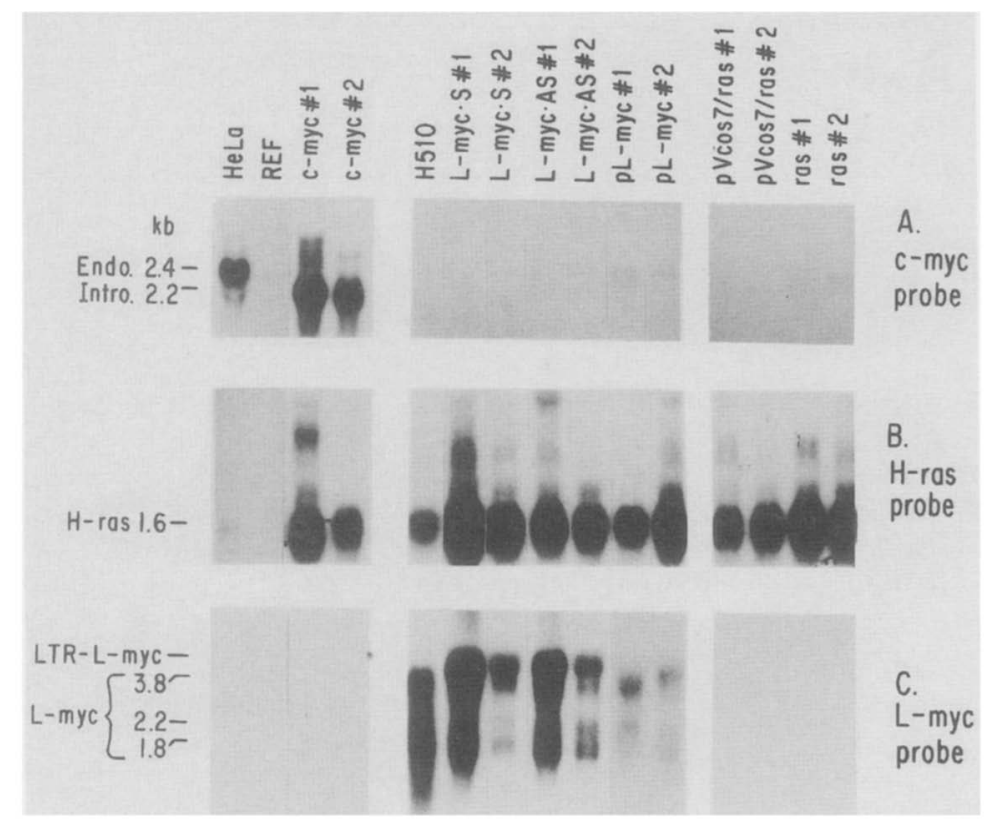

gene containing a small poly(A) stretch that is flanked by directly repeated sequences. Our preliminary mapping data indicate that L-myc $\psi$ is located on human chromosome X (R. DePinho et al., in prep.); previous studies have assigned the L-myc gene to human chromosome 1 (Nau et al. 1985).

\section{Discussion}

\section{$L$-myc is the third member of the myc oncogene family}

Our results clearly demonstrate that the human L-myc gene represents an additional functional member of the myc-family of cellular oncogenes. This conclusion is based on the observation that the L-myc gene and gene product share oncogenic activities and structural features with the other well-characterized myc-family members. The common and divergent structural elements described in this report could provide direction in the preliminary dissection of potential functional domains in the L-myc and other myc proteins. For example, c-myc encodes a nuclear protein that has DNAbinding capacity in vitro (Donner et al. 1982; Persson and Leder 1984; Watt et al. 1985), a property attributed to the abundance of basic amino acids at its carboxyl terminus (Persson and Leder 1984). This structural feature is also present in the putative L-myc gene product; thus, the L-myc protein may also be a nuclear protein with capacity to bind nucleic acids. In general, we have also found that most c-myc protein domains necessary for cotransformation activity, nuclear targeting, and retention in the nucleus are well conserved in the L-myc protein. Moreover, extremely well-conserved residues that we have identified within these potential functional domains may further delineate critical residues involved in these properties. However, not all of the c-myc domains are conserved in $\mathrm{L}-\mathrm{myc}$; one region that appears important for nuclear targeting in c-myc is not conserved in the putative L-myc gene product. Despite the striking degree of conservation of various sequences and aspects of function (e.g., activity in the REF cotransformation assayl, the conservation of the $\mathrm{c}-^{-} \mathrm{N}-$-, and L-myc genes throughout vertebrate evolution as distinct sequences suggests unique physiological activities (see below for further discussion of this point). In this context, the potential roles of the extremely divergent regions that appear at common positions within the various myc proteins or regions conserved only between $\mathrm{N}$ - and c-myc need to be assessed.

The mouse and human L-myc untranslated regions are well conserved. This remarkable degree of sequence conservation in regions that are not under any selective pressure at the protein level is consistent with a role in the regulation of gene expression. In contrast to the remarkable evolutionary conservation within a given myc-family gene, untranslated sequences among the different myc family members are totally divergent from each other. The different myc-family genes have very distinct expression patterns (Alt et al. 1986; Zimmerman et al. 1986); in this context, it is conceivable that evolutionarily conserved flanking sequences unique to each family member somehow could be involved in mediating differential expression.

\section{$L$-myc transforming activity}

A large body of evidence has suggested that progression to malignancy is a multistep process (for review, see Weinberg 1985). Thus, the c-myc gene has been linked with immortalization activity (Mougneau et al. 1984; Ruley et al. 1984) while the action of Ha-ras has been correlated with transformation activity (Land et al. 1983; Ruley et al. 1983|. Additional studies, however, indicate that $\mathrm{c}-\mathrm{myc}$ expression constructs can induce 
transformation in immortalized cell lines (Keath et al. 1984; Kelekar and Cole 1986) and that Ha-ras can immortalize primary cells (Spandidos and Wilkie 1984). Currently, it is not clear how the activities of these genes result in the observed spectrum of deregulated growth. We have demonstrated that the L-myc gene can cooperate with a mutant Ha-ras gene to malignantly transform rat embryo fibroblasts. Although we could not detect a difference in the malignant phenotype between the L-myc/ras transformants and the $\mathrm{N}$ - or c-myc/ras transformants, the L-myc/ras transformants did arise at a lower frequency. If the three myc genes encode proteins with identical transforming activities, the different efficiencies in the REF transformation assay might result from constructs with different capacities to produce sufficient levels of the respective myc proteins. However, in this regard, it is surprising that the L-myc gene was able to cooperate with ras in the absence of a retroviral enhancer because the $\mathrm{N}-m y c$ gene seemed to require the presence of associated transcriptional enhancer elements. Alternatively, it is possible that the L-myc gene product may not possess a transforming activity equivalent to that of the c- or $\mathrm{N}-m y c$ proteins and/or may require additional genetic events to achieve the malignant phenotype; both these possibilities could result in diminished activity of L-myc in this assay.

We have demonstrated that the transforming activity of L-myc is not limited to the very restricted set of tumors in which the gene has been found to be amplified and overexpressed (to date, only in a subset of SCLC). The apparently limited involvement of L-myc in the genesis of naturally occurring tumors is also observed for $\mathrm{N}$-myc (clearly implicated only in neuroblastomas and some retinoblastomas and SCLCl, but contrasts with that of $c-m y c$, which appears to participate in the neoplastic transformation of a much wider variety of cells (for review, see Alt et al. 1986). We have recently demonstrated that the restricted set of tumors in which the $\mathrm{N}$ - and L-myc genes are amplified and/or overexpressed correlates in part with the tissue- and stage-specific expression patterns of these genes during normal development (Nisen et al. 1986; Zimmerman et al. 1986). Given our current observation that L-myc, like $\mathrm{N}-m y c$, can participate in the in vitro transformation of other cell types (fibroblasts), which do not even express detectable levels of either gene, it seems possible that deregulated expression of these genes contributory to the development of naturally occurring tumors may occur preferentially in cell types that actively express the genes. Another, not mutually exclusive, possibility for the restricted contribution of $\mathrm{N}$ - and L-myc to natural tumors is that the activity of the different myc gene products may be effected in a tissue-specific fashion. It is notable that, to date, the only observed mechanism for activated expression of the $\mathrm{N}$ - and L-myc genes in naturally occurring tumors is by gene amplification (for review, see Alt et al. 1986) and that expression levels of $\mathrm{N}$ or L-myc genes in REF transformants often approach those of some amplified tumors (e.g., Fig. 5). To achieve high-level amplification, a gene usually must give some selective growth advantage at low amplification (expres- sion) levels, with the selective advantage increasing at higher levels (Schimke 1984; Alt et al. 1986). One possible rationalization for the apparently disparate transforming activities of the $\mathrm{L}$ - and $\mathrm{N}$-myc genes in vivo as opposed to in vitro could be that the relatively high-level expression observed in nearly all in vitro transformants leads to a more degenerate transforming activity than would occur with small increases that initially occur in an amplification process (in vivo). In this regard, a threshold level of $\mathrm{N}-m y c$ expression is necessary for regulation of MHC Class I gene expression (Bernards et al. 1986).

\section{Methods}

Genomic and CDNA cloning

Genomic DNA from human placenta was digested to completion with EcoRI and cloned into the EcoRI site of $\lambda$ phage Charon 30 essentially as described previously (DePinho et al. 1985). This library was screened for clones that hybridized to exons 2 (400-bp XhoI-BamHI fragment) and 3 (1100-bp EcoRI*-HinclI fragment) under low stringency conditions as described by Legouy et al. 1987.

Primer-extension and oligo(dT)-primed cDNA libraries were prepared from cytoplasmic poly $(\mathrm{A})^{+}$RNA isolated from the H510 SCLC cell line (graciously provided by John Minna) and 1C.1, an L-myc-expressing REF transformant cell line (see text), as described previously (Kohl et al. 1986; Legouy et al. 1987). This library was screened for clones which hybridized to exons 1 and 2 L-myc-specific probes; probes are illustrated and described in Figure 2. Several clones were isolated and subcloned into the pUC18 plasmid vector for further analysis.

\section{DNA sequencing}

The nucleotide sequence of indicated regions of the CDNA and genomic clones was determined by the partial chemical degradation method of Maxam and Gilbert (1977).

\section{Analysis of RNA and DNA}

DNA and RNA preparation, restriction endonuclease digestions, probe preparation by the nick-translation method, blotting procedures, and hybridization conditions were performed as described previously (DePinho et al. 1985). Reduced-stringency hybridizations were performed in $35 \%$ formamide, $5 \times$ SSCPE, $10 \%$ dextran sulfate, $1 \times$ Denhardt's solution, and 100 $\mu \mathrm{g} / \mathrm{ml}$ salmon sperm DNA; washing was conducted at $56^{\circ} \mathrm{C}$ in $2 \times$ SSC and $0.1 \%$ SDS; all other conditions follow standard procedures as described previously (DePinho et al. 1985).

\section{Preparation and transfection of REFs}

Early-passage cultures of REFs were prepared as described elsewhere (Yancopoulos et al. 1985) from 12- to 14-day Fischer rat embryos. REFs were initially plated at near-confluent density and allowed to grow to confluence. To prepare for transfection, REFs were then replated after $1-2$ days at $1.5 \times 10^{6}$ cells per $10-\mathrm{cm}$ plate in Dulbecco's modified Eagle's medium supplemented with $10 \%$ fetal bovine serum. DNA was introduced into REFs by calcium phosphate precipitation as described previously (Andersson et al. 1979) using $30 \mu \mathrm{g}$ of human placental carrier DNA with $2 \mu \mathrm{g}$ of each of the appropriate plasmid DNAs per plate. The cultures were refed 6-9 hr after transfection and split $18 \mathrm{hr}$ after the transfection into either three (ex- 
periments 1 and 2) or four (experiment 3) plates. Assuming that limited cell division occurs in the $24 \mathrm{hr}$ after the transfection, each plate after this final passage contains independent transformants. This was verified by DNA analysis of isolated transformants (data not shown). The various plasmids used in the REF transfections are as follows: pT24-ras contains the mutant Ha-ras oncogene with (experiments 2 and 3 ) and without (experiment 1) a neomycin resistance gene (Fasano et al. 1983; provided by $\mathrm{M}$. Goldfarb); the pKO-myc plasmid, kindly provided by Daniel Birnbaum, is a c-myc expression construct in which transcription of the second and third exons of c-myc is driven from a simian virus 40 promoter; the L-myc constructs are described below and illustrated in Table 1, bottom.

\section{Assay for colony formation in soft agar}

A single-cell suspension of approximately $1 \times 10^{4}$ cells in $5 \mathrm{ml}$ of $0.28 \%$ agar was overlaid onto a $60-\mathrm{mm}$ culture dish containing a $0.7 \%$ agar base. All agar suspensions were made in Dulbecco's modified Eagle's medium supplemented with $10 \%$ fetal bovine serum. Duplicate plates were prepared for each tested line. Normal REFs propagated in culture served as a nontransformed control for these studies.

\section{Assay for tumorigenicity}

Cell lines propagated from transformed foci (see text) were assayed for tumorigenicity by subcutaneously injecting $1 \times 10^{6}$ to $5 \times 10^{6}$ cells in $0.4 \mathrm{ml}$ of PBS into 5- to 10-day-old syngeneic Fischer rats. Each line tested was injected into at least two rats. A nontransfected control was provided by propagating normal REFs in culture until sufficient numbers of cells were attained; four rats each injected with $2 \times 10^{7}$ normal REFs served as controls. The rats were followed until death, or for 4 weeks in the case of the normal REF injections.

\section{Computer analysis of DNA and protein sequence}

Computer analyses of the L-myc sequence were performed on an IBM-AT personal computer using the Microgenie Sequence Analysis Program (SciSoft, Inc.).

\section{Acknowledgments}

We would like to thank Stephanie Goei for assistance in multiple phases of this project; Drs. Mitchell Goldfarb, Gary Rathbun, Scott Mellis, Kathy Zimmerman, Russell Smith, Robert Collum, and Connie Gee for critical reading of this manuscript; and Drs. Fred Kaye and John Minna for exchanging nucleotide sequences before publication of this manuscript. We would also like gratefully to acknowledge the support of the Howard Hughes Medical Institute and National Institutes of Health grants CA23767-06 and CA42335 and American Cancer Society grant CD-269. F.A. is an Irma T. Hirschl Career Scientist and a Malinckrodt Scholar. R.D. is a recipient of a National Institutes of Health physician scientist award (NIH AI0060204). K.H. was supported by a postdoctoral fellowship from a National Research Service Award awarded by the National Cancer Institute (CA07744). G.D.Y. is a postdoctoral fellow of the Howard Hughes Medical Institute.

\section{References}

Abrams, H.D., L.R. Rohrschneider, R.N. Eisenman. 1982. Nuclear location of the putative transforming protein of avian myelocytomatosis virus. Cell 29: 427-439.
Adams, J., A. Harris, C. Pinkert, L. Corcoran, W. Alexander, S. Cory, R. Palmiter, and R. Brinster. 1985. The c-myc oncogene driven by Ig enhancers induces lymphoid malignancy in transgenic mice. Nature 318: 533-538.

Alitalo, K., G. Ramsay, J.M. Bishop, S. Pfeifer-Ohlsson, W.W. Colby, and A.D. Levinson. 1983. Identification of nuclear proteins encoded by viral and cellular myc oncogenes. $\mathrm{Na}$ ture 306: 274-277.

Alt, F.W., R.A. DePinho, K. Zimmerman, E. Legouy, K. Hatton, P. Ferrier, A. Tesfaye, G.D. Yancopoulos, and P. Nisen. 1986. The human myc-gene family. Cold Spring Harbor Symp. Quant. Biol. 51: 931-941.

Alt, F., E. Harlow, and E. Ziff. 1987. Nuclear oncogenes. Cold Spring Harbor Laboratory, Cold Spring Harbor, New York, (In press).

Andersson, P., M.P. Goldfarb, and R.A. Weinberg. 1979. A defined subgenic fragment of in vitro synthesized Moloney sarcoma virus DNA can induce cell transformation upon transfection. Cell 16: 63-75.

Battey, J., C. Moulding, R. Taub, W. Murphy, T. Stewart, H. Potter, G. Lenoir, and P. Leder. 1983. The human c-myc oncogene: Structural consequences of translocation into the IgH locus in Burkitt lymphoma. Cell 34: 779-787.

Bernard, O., S. Cory, S. Gerondakis, E. Webb, and J.M. Adams. 1983. Sequence of the murine and human cellular myc oncogenes and two modes of myc transcription resulting from chromosome translocation in B lymphoid tumours. EMBO $J$. 2: 2375-2383.

Bernards, R., S.K. Dessain, and R.A. Weinberg. 1986. N-myc amplification causes down-modulation of MHC Class I antigen expression in neuroblastoma. Cell 47: 667-674.

Coppola, J.A. and M.C. Cole. 1986. Constitutive c-myc oncogene expression blocks MEL cell differentiation but not commitment. Nature 320: 760-763.

DePinho, R.A., K. Kruger, N. Andrews, S. Lutzker, D. Baltimore, and F.W. Alt. 1985. Molecular basis of heavy-chain class switching and switch region deletion in an Abelson virus-transformed cell line. Mol. Cell. Biol. 4: 2905- 2910.

DePinho, R.A., E. Legouy, L.B. Feldman, N.E. Kohl, G.D. Yancopoulos, and F.W. Alt. 1986. Structure and expression of the murine N-myc gene. Proc. Natl. Acad. Sci. 83: 18271831.

DePinho, R.A., L. Mitsock, K. Hatton, P. Ferrier, K. Zimmerman, E. Legouy, A. Tesfaye, R. Collum, G. Yancopoulos, P. Nisen, R. Kriz, and F. Alt. 1987. myc family of cellular oncogenes. I. Cell. Biochem. 33: 257-266.

Dmitrovsky, E., W.M. Kuehl, G.F. Hollis, I.R. Kirsh, T.P. Bender, and S. Segal. 1986. Expression of a transfected human c-myc oncogene inhibits differentiation of a mouse erythroleukemia cell line. Nature 322: 748-750.

Donner, P., I. Greiser-Wilke, and K. Moelling. 1982. Nuclear localization and DNA binding of the transforming gene product of avian myelocytomatosis virus. Nature 296: 262266.

Fasano, O., E. Taparowsky, J. Fiddes, M. Wigler, and M. Goldfarb. 1983. Sequence and structure of the coding region of the human H-ras-1 gene from T24 bladder carcinoma cells. J. Mol. Appl. Genet. 2: 173-180.

Hann, S.R., H.D. Abrams, L.R. Rorshneider, and R.N. Eisenman. 1983. Proteins encoded by v-myc and c-myc oncogenes: Identification and localization in acute leukemia virus transformants and bursal lymphoma cell lines. Cell 34: 789-798.

Hann, S.R. and R.N. Eisenman. 1984. Proteins encoded by the human c-myc oncogene: Differential expression in neoplastic cells. Mol. Cell. Biol. 4: 2486-2497. 
Hopp, T.P. and K.R. Woods. 1981. Prediction of protein antigenic determinants from amino acid sequences. Proc. Natl. Acad. Sci. 78: 3824-3828.

Ikegaki, N., J. Bukovsky, and R.H. Kennett. 1986. Identification and characterization of $\mathrm{N}-\mathrm{myc}$ gene product in human neuroblastoma cells by monoclonal antibodies with defined specificities. Proc. Natl. Acad. Sci. 83: 5929-5933.

Jakobovits, A., M. Schwab, J.M. Bishop, and G.R. Martin. 1985. Expression of $\mathrm{N}-\mathrm{myc}$ in teratocarcinoma stem cells and mouse embryos. Nature 318: 188-191.

Keath, E.J., P.G. Caimi, and M.D. Cole. 1984. Fibroblast lines expressing activated c-myc oncogenes are tumorigenic in nude mice and syngeneic animals. Cell 39: 339-348.

Kelekar, A. and M.D. Cole. 1986. Tumorigenicity of fibroblast lines expressing the adenovirus E1A, cellular p53, and normal c-myc genes. Mol. Cell. Biol. 6: 7-14.

Kelly, K. and U. Siebenlist. 1986. The regulation and expression of c-myc in normal and malignant cells. Annu. Rev. Immunol. 4: 327-338.

King, M.W., J.M. Roberts, and R.N. Eisenman. 1986. Expression of the c-myc proto-oncogene during development of Xenopus laevis. Mol. Cell. Biol. 6: 4499-4508.

Kohl, N.E., N. Kanda, R.R. Schreck, G. Bruns, S.A. Latt, F. Gilbert, and F.W. Alt. 1983. Transposition and amplification of oncogene-related sequences in human neuroblastomas. Cell 35: 359-367.

Kohl, N.E., E. Leguoy, R.A. DePinho, R. Smith, C. Gee, and F.W. Alt. 1986. Human N-myc is closely related in organization and nucleotide sequence to c-myc. Nature 319: 73-77.

Lachman, H.M., G. Cheng, and A.I. Skoultchi. 1986. Transfection of mouse erythroleukemia cells with myc sequences changes the rate of induced commitment to differentiation. Proc. Natl. Acad. Sci. 83: 6480-6484.

Land, H., L.F. Parada, and R.A. Weinberg. 1983. Tumorigenic conversion of primary embryo fibroblasts requires at least two cooperating oncogenes. Nature 304: 596-601.

Legouy, E., R.A. DePinho, K. Zimmerman, R. Collum, G.D. Yancopoulos, L. Mitsock, R. Kriz, and F.W. Alt. 1987. Structure and expression of the murine L-myc gene. EMBO I., (In press).

Minna, J.D., J.F. Battey, B.J. Brooks, F. Cuttitta, A.F. Gazdar, B.E. Johnson, D.C. Ihde, A.M. Lebacq-Verheyden, J. Mulshine, M.M. Nau, H.K. Oie, E.A. Sausville, E. Seifter, and M. Vinocour. 1986. Molecular genetic analysis reveals chromosome deletion, gene amplification, and autocrine growth factor production in the pathogenesis of human lung cancer. Cold Spring Harbor Symp. Quant. Biol. 51: 843-853.

Mougneau, E., L. Lemieux, M. Rassoulzadegan, and F. Cuzin. 1984. Biological activities of v-myc and rearranged c-myc oncogenes in rat fibroblast cells in culture. Proc. Natl. Acad. Sci. 81: 5758-5762.

Mount, S.M. 1982. A catalog of splice junction sequences. $\mathrm{Nu}$ cleic Acids Res. 10: 459-472.

Nau, M., B. Brooks, J. Battey, E. Sausville, A. Gasdar, I. Kirsh, O. McBride, V. Bertness, G. Hollis, and J. Minna. 1985. L-myc, a new myc-related gene amplified and expressed in human small cell lung cancer. Nature 318: 69-73.

Nisen, P.D., K.A. Zimmerman, S.V. Cotter, F. Gilbert, and F.W. Alt. 1986. Enhanced expression of the N-myc gene in Wilms tumors. Cancer Res. 46: 6217-6222.

Persson, H. and P. Leder. 1984. Nuclear localization and DNA binding properties of a protein expressed by human c-myc oncogene. Science 225: 718-721.

Persson, H., H.E. Gray, F. Godeau, S. Braunhut, and A.R. Bellve. 1986. Multiple growth associated nuclear proteins immuno- precipitated by antisera raised against human c-myc peptide antigens. Mol. Cell. Biol. 6: 942-949.

Proudfoot, N.J. and G.G. Brownlee. 1976. 3' non-coding region sequences in eukaryotic messenger RNA. Nature 263: 211214.

Ralston, R. and J.M. Bishop. 1983. The protein products of the $m y c$ and $M y b$ oncogenes and adenovirus E1A are structurally related. Nature 306: $803-806$.

Ramsay, G., G.I. Evan, and J.M. Bishop. 1984. The protein encoded by the human proto-oncogene c-myc. Proc. Natl. Acad. Sci. 81: 7742-7746.

Ruley, H.E. 1983. Adenovirus early region 1A enables viral cellular transforming genes to transform primary cells in culture. Nature 304: 602-606.

Ruley, H.E., J.F. Moomaw, and K. Maruyama. 1984. Avian myelocytomatosis virus myc and adenovirus early region $1 \mathrm{~A}$ promote the in vitro establishment of cultured primary cells. Cancer cells 2: 481-486. Cold Spring Harbor Laboratory, Cold Spring Harbor, New York.

Schimke, R.T. 1984. Gene amplification in cultured animal cells. Cell 37: 705-713.

Schwab, M., K. Alitalo, L. Klempnauer, H. Varmus, J. Bishop, F. Gilbert, G. Brodeur, M. Goldstein, and J. Trent. 1983. Amplified DNA with limited homology to myc cellular oncogene is shared by human neuroblastoma cell lines and a neuroblastoma tumor. Nature 305: 245-248.

Schwab, M., H.E. Varmus, and J.M. Bishop. 1985. The human $\mathrm{N}$-myc gene contributes to tumorigenic conversion of mammalian cells in culture. Nature 316: 160-162.

Sheiness, D. and J.M. Bishop. 1979. DNA and RNA from uninfected vertebrate cells contain nucleotide sequences related to the putative transforming gene of avian myelocytomatosis virus. I. Virol. 31: 514-521.

Slamon, D.J., T.C. Boone, R.C. Seeger, D.E. Keith, V. Chazin, H.C. Lee, and L.M. Souza. 1986. Identification and characterization of the protein encoded by the human N-myc oncogene. Science 232: 768-772.

Spandidos, D.A. and I.M. Wilkie. 1984. Malignant transformation of early passage rodent cells by a single mutant human oncogene. Nature 310: 469-475.

Spector, D.L., R.A. Watt, and N.F. Sullivan. 1987. The v- and c-myc proteins colocalize in situ with small nuclear ribonucleoprotein particles. Oncogene 1: 5-12.

Stanton, L., M. Schwab, and J.M. Bishop. 1986. Nucleotide sequence of the human N-myc gene. Proc. Natl. Acad. Sci. 83: $1772-1776$.

Stone, J., T. DeLange, G. Ramsay, E. Jakobovits, J.M. Bishop, H.E. Varmus, and W. Lee. 1987. Definition of regions in human c-myc involved in transformation and nuclear localization. Mol. Cell. Biol. 7: 1697-1709.

Van Beneden, R.J., D.K. Watson, T.T. Chen, J.A. Lautenberger, and T.S. Papas. 1986. Cellular myc (c-myc) in fish (rainbow trout): Its relationship to other vertebrate myc genes and to the transforming genes of the MC29 family of viruses. Proc. Natl. Acad. Sci. 83: 3698-3702.

Vanin, E.F. 1984. Processed pseudogenes: Characteristics and evolution. Biochim. Biophys. Acta 782: 231-241.

Watt, R.A., A.R. Shatzman, and M. Rosenberg. 1985. Expression and characterization of the human c-myc DNA-binding protein. Mol. Cell. Biol. 5: 448-456.

Weinberg, R.A. 1985. The action of oncogenes in the cytoplasm and nucleus. Science 230: 770-776.

Yancopoulos, G.D., P.D. Nisen, A. Tesfaye, N.E. Kohl, M.P. Goldfarb, and F.W. Alt. 1985. N-myc can cooperate with ras to transform normal cells in culture. Proc. Natl. Acad. Sci. 82: $5455-5459$. 
DePinho et al.

Zimmerman, K.A., G.D. Yancopoulos, R.G. Collum, R.K. Smith, N.E. Kohl, K.A. Denis, M.M. Nau, O.N. Witte, D.

Toran-Allerand, C.E. Gee, J.D. Minna, and F.W. Alt. 1986.

Differential expression of myc family genes during murine development. Nature 319: 780-783. 


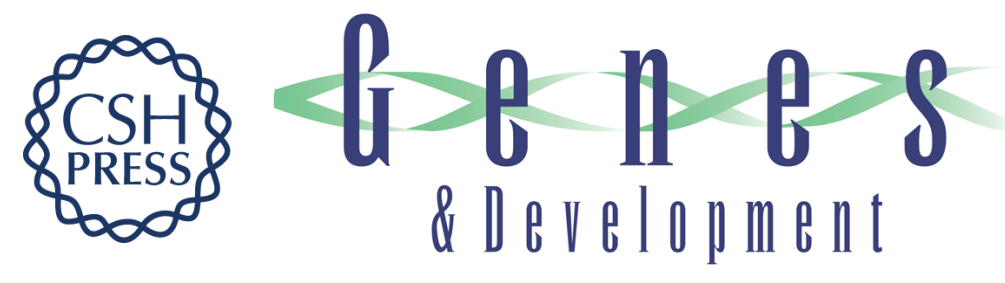

\section{The human myc gene family: structure and activity of L-myc and an L-myc pseudogene.}

R A DePinho, K S Hatton, A Tesfaye, et al.

Genes Dev. 1987, 1:

Access the most recent version at doi:10.1101/gad.1.10.1311

References This article cites 54 articles, 21 of which can be accessed free at: http://genesdev.cshlp.org/content/1/10/1311.full.html\#ref-list-1

License

Email Alerting

Receive free email alerts when new articles cite this article - sign up in the box at the top Service right corner of the article or click here.

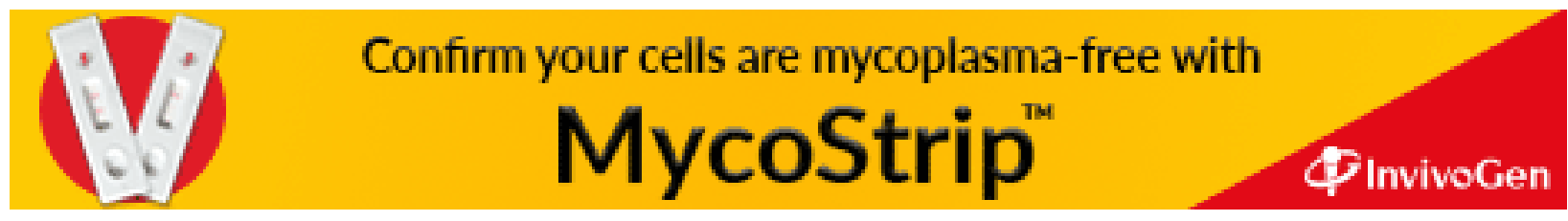

